\title{
Molecular mechanisms of TNF- $\alpha$-induced ceramide formation in human glioma cells:P53-mediated oxidant stress-dependent and -independent pathways
}

\author{
M Sawada*,1, T Kiyono ${ }^{2}$, S Nakashima ${ }^{3}$, J Shinoda ${ }^{1}$, \\ T Naganawa ${ }^{3}$, S Hara ${ }^{1}$, T Iwama ${ }^{1}$ and N Sakai ${ }^{1}$ \\ 1 Department of Neurosurgery, Gifu University School of Medicine, \\ Tsukasamachi-40, Gifu 500-8705, Japan \\ 2 Virology Division, National Cancer Center Research Institute, 5-1-1 Tsukiji, \\ Chuohku, Tokyo 104-0045, Japan \\ ${ }^{3}$ Department of Cell Signaling, Division of Cellular and Molecular Biology, \\ Gifu University School of Medicine, Tsukasamachi-40, Gifu 500-8705, Japan \\ * Corresponding author: M Sawada, Department of Neurosurgery, Gifu \\ University School of Medicine, Tsukasamachi-40, Gifu 500-8705, Japan. \\ Tel: + 81-58-267-2348; Fax: + 81-58-265-9025; \\ E-mail: sawasawa@cc.gifu-u.ac.jp
}

Received 22.7.03; revised 13.1.04; accepted 04.2.04; published online 07.5.04 Edited by ME Peter

\begin{abstract}
The present study was designed to examine the roles of $\mathrm{p} 53$, reactive oxygen species (ROS), and ceramide, and to determine their mutual relationships during tumor necrosis factor (TNF)- $\alpha$-induced apoptosis of human glioma cells. In cells possessing wild-type p53, TNF- $\alpha$ stimulated ceramide formation via the activation of both neutral and acid sphingomyelinases (SMases), accompanied by superoxide anion $\left(\mathrm{O}_{2}^{-}\right)$production, and induced mitochondrial depolarization and cytochrome $c$ release, whereas p53-deficient cells were partially resistant to TNF- $\alpha$ and lacked $\mathrm{O}_{2}^{-\bullet}$ generation and neutral SMase activation. Restoration of functional p53 sensitized glioma cells expressing mutant p53 to TNF- $\alpha$ by accumulation of $\mathrm{O}_{2}^{-\bullet}$. z-IETD-fmk (benzyloxycarbonyl-Ile-GluThr-Asp fluoromethyl ketone), but not z-DEVD-fmk (benzyloxycarbonyl-Asp-Glu-Val-Asp fluoromethyl ketone), blocked TNF- $\alpha$-induced ceramide formation through both SMases as well as $\mathrm{O}_{2}^{-\bullet}$ generation. Caspase-8 was processed by TNF- $\alpha$ regardless of p53 status of cells or the presence of antioxidants. Two separate signaling cascades, p53-mediated ROS-dependent and -independent pathways, both of which are initiated by caspase-8 activation, thus contribute to ceramide formation in TNF- $\alpha$-induced apoptosis of human glioma cells.
\end{abstract}

Cell Death and Differentiation (2004) 11, 997-1008.

doi:10.1038/sj.cdd. 4401438

Published online 7 May 2004

Keywords: ceramide; glioma; p53; reactive oxygen species; TNF- $\alpha$

Abbreviations: ROS, reactive oxygen species; $\mathrm{O}_{2}^{-\bullet}$, superoxide anion; $\mathrm{H}_{2} \mathrm{O}_{2}$, hydrogen peroxide; ${ }^{\circ} \mathrm{OH}$, hydroxyl radical; TNF, tumor necrosis factor; SM, sphingomyelin; SMase, sphingomye- linase; N-SMase, neutral sphingomyelinase; A-SMase, acid sphingomyelinase; HPV, human papillomavirus; $\mathrm{CHX}$, cycloheximide; SR33557, ((2-isopropyl-1-(4-[3- $N$-methyl- $N$-(3,4dimethoxy-beta-phenethyl)amino]propyloxy)-benzenesulfonyl)) indolizine; FB1, fumonisin B1; SOD, superoxide dismutase; HE, hydroethidium; DCFH-DA, 2',7'-dichlorofluorescein diacetate; DCF, 2', 7'-dichlorofluorescein; GSH, reduced glutathione; MTp53ts, temperature-sensitive human p53 val ${ }^{138}$ mutant; $\Delta \psi_{\mathrm{m}}$, mitochondrial transmembrane potential; $\mathrm{DiOC}_{6}(3), 3,3$-dihexyloxacarbocyanine iodide; z-IETD-fmk, benzyloxycarbonyl-IleGlu-Thr-Asp fluoromethyl ketone; z-DEVD-fmk, benzyloxycarbonyl-Asp-Glu-Val-Asp fluoromethyl ketone; CA074 Me, [L-3-trans(propylcarbamoyl)oxirane-2-carbonyl]-L-isoleucyl-L-proline methyl ester; NAC, $\mathrm{N}$-acetylcysteine; shRNA, short hairpin RNA; DMEM, Dulbecco's modified Eagle's medium; FBS, fetal bovine serum; HPTLC, high-performance thin-layer chromatography; SDSPAGE, sodium dodecylsulfate polyacrylamide gel electrophoresis

\section{Introduction}

Cellular redox state is an important factor in determining susceptibility to different apoptotic stimuli. Reactive oxygen species (ROS), including superoxide $\left(\mathrm{O}_{2}^{-\bullet}\right)$, hydrogen peroxide $\left(\mathrm{H}_{2} \mathrm{O}_{2}\right)$, and hydroxyl radical $\left({ }^{\circ} \mathrm{OH}\right)$, are now recognized as signaling molecules that are mobilized in response to stimuli. Treatment of mammalian cells with tumor necrosis factor (TNF)- $\alpha$ triggers generation of various ROS. ${ }^{1-4}$ Antioxidants inhibit various effects of TNF- $\alpha$, and the cell signaling induced by exogenous ROS is quite similar to TNF- $\alpha$ signaling. 5,6 These findings support the hypothesis that ROS serve as crucial second messengers for the TNF- $\alpha$ signaling pathway. TNF- $\alpha$ has been shown to induce accumulation of $p 53$ in various types of cells including glioma cells, suggesting the possibility of involvement of p53 in TNF$\alpha$-induced cell death. ${ }^{7-10}$ Accumulating evidence suggests a role for ROS as a potential mediator of p53-dependent apoptosis. ${ }^{11-13}$ ROS might thus play a crucial role downstream of p53 during TNF- $\alpha$ signaling. Currently, however, the mechanism by which cellular redox state is regulated during TNF- $\alpha$-induced apoptosis and the role of ROS in modulating cell death remain unclear.

The generation of ceramide, the hydrolyzed product of the phospholipid sphingomyelin (SM), has been proposed as another mechanism participating in TNF- $\alpha$-mediated apoptosis. ${ }^{14}$ Enzymes that hydrolyze SM, such as sphingomyelinases (SMases), are regulators of intracellular ceramide levels and consequently ceramide-mediated events. These enzymes are key components of the so-called SM pathway, an ubiquitous system that functions in transducing cytokine signals to the cell interior. ${ }^{15,16}$ SMase is known to exist in at least two forms, neutral (N-) and acid (A-), depending on their 
intracellular location and $\mathrm{pH}$ optima. ${ }^{15,16}$ Although it appears that both $\mathrm{N}$ - and A-SMases play important roles in TNF- $\alpha$ signaling, ${ }^{17}$ the molecular mechanisms by which SMases are activated and recruited during signaling are unclear. In addition, a recent study indicated that ROS participate in TNF- $\alpha$-mediated ceramide formation, ${ }^{18}$ suggesting that the ROS-sensitive pathway may be located upstream of ceramide formation. In contrast, another study demonstrated that ceramide plays a role as an intermediate in TNF- $\alpha$-mediated ROS production. ${ }^{3}$ The mutual relationship between ROS and the SM pathway during TNF- $\alpha$-induced apoptosis thus remains poorly understood.

In this study, we examined the involvement of p53, ROS and ceramide in the apoptotic signaling cascade, and their mutual relationships in TNF- $\alpha$-treated human glioma cells. Based on the findings obtained in this study, we propose the existence of at least two separate signaling cascades in TNF$\alpha$-induced ceramide formation in human glioma cells: one is ROS dependent and the other is ROS independent. ROS generation, an upstream event in the cell death process, requires functional p53 and is dependent on the activation of caspase-8.

\section{Results}

\section{Disruption of functional p53 by human papillomavirus type 16 (HPV-16) E6 infection inhibits TNF- $\alpha$-induced apoptosis and ceramide formation}

In the glioma cells tested, human recombinant TNF- $\alpha$ alone (up to $1 \mu \mathrm{g} / \mathrm{ml}$ ) displayed no evidence of cytotoxity after incubation for $24 \mathrm{~h}$ (data not shown). However, in combination with $1 \mu \mathrm{g} / \mathrm{ml}$ cycloheximide $(\mathrm{CHX})$, the number of apoptotic cells increased in proportion to the concentration of TNF- $\alpha$ (data not shown). In subsequent experiments, cells were treated with $100 \mathrm{ng} / \mathrm{ml} \mathrm{TNF}-\alpha$ in the presence of $1 \mu \mathrm{g} / \mathrm{ml} \mathrm{CHX}$.

Inactivation of p53 was accomplished by the expression of E6 protein of HPV-16, which binds p53 and accelerates its proteolytic degradation through the ubiquitin pathway. ${ }^{19-21}$ Using a retroviral vector, wild-type or mutant E6 proteins and empty vector were expressed in U-87 MG human glioma cells (designated as U87-W E6, U87-M E6, and U87-LXSN, respectively), as shown previously. ${ }^{22}$ The mutant E6 (16E6SD-8S9A10T) has substitutions of the amino acids Arg, Pro, and Arg at positions 8, 9, and 10 with the corresponding amino acids, Ser, Ala, and Thr, respectively, from the 'low-risk' type 11 HPV E6, and does not degrade p53 but performs the other known E6 functions such as activation of telomerase. ${ }^{23}$ TNF- $\alpha$ caused time-dependent accumulation of p53 protein in U87-LXSN and U87-M E6 cells (Figure 1a and $c$ ). During the time course examined, however, expression of wild-type E6 protein abrogated upregulation of p53 following TNF- $\alpha$ treatment in U87-W E6 cells (Figure 1b). In addition, TNF- $\alpha$ failed to induce p53 upregulation in U-373 MG (Figure 1d) and U-251 MG cells (data not shown), both of which expressed mutant p53. ${ }^{24}$ Moreover, p53 was virtually inactivated by E6 protein, as confirmed by the lack of accumulation of p53-dependent proteins such as p21 and Bax in U87-W E6, but not in U87-LXSN or U87-M E6 cells
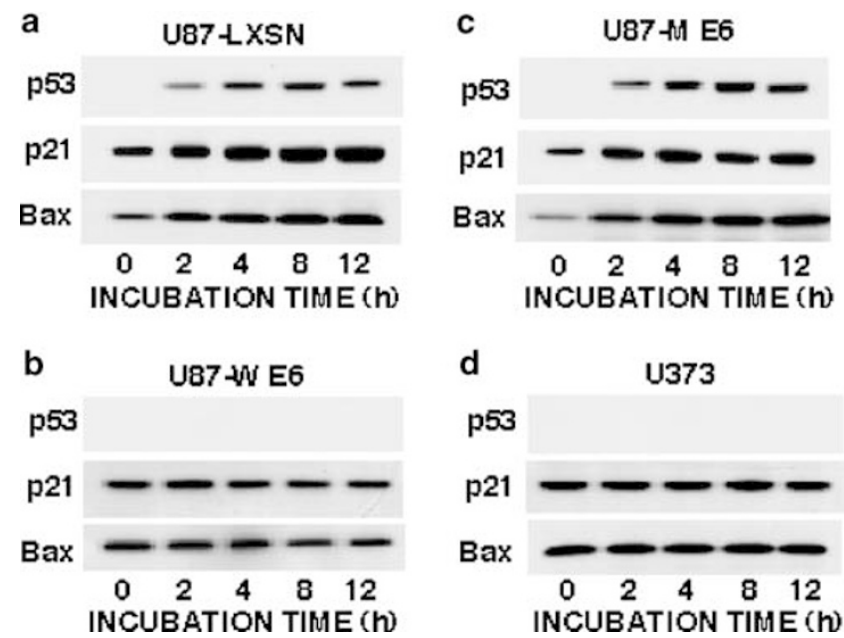

Figure 1 Expression of p53 and p53-dependent proteins during TNF- $\alpha$ treatment in human glioma cells. U87-LXSN (a), U87-M E6 (b), and U87-W E6 cell lines (c) were obtained by infecting U-87 MG cells with LXSN, LXSN16E6SD, and LXSN-16E6SD-8S9A10T retroviruses, respectively. These cells and U-373 MG cells (d) expressing mutant p53 protein were treated with $100 \mathrm{ng} /$ $\mathrm{ml} \mathrm{TNF}-\alpha$ plus $1 \mu \mathrm{g} / \mathrm{ml} \mathrm{CHX}$ for indicated periods. Cellular proteins were subjected to SDS-PAGE and immunoblotted with antibodies against p53, Bax, and $p 21$. Data are representative of three separate experiments with compatible outcomes

(Figure $1 \mathrm{a}-\mathrm{c}$ ). Taken together, these findings proved that functional p53 of U-87 MG cells is downregulated by E6 protein expression. As shown in Figure 2a, U87-LXSN and U87-M E6 cells expressing wild-type p53 were more sensitive to TNF- $\alpha$ cytotoxicity than U-251 MG and U-373 MG cells possessing mutant p53. In contrast, U87-W E6 cells became partially resistant to $T N F-\alpha$. These findings suggest that functional p53 plays a role in mediating TNF- $\alpha$ cytotoxicity.

TNF- $\alpha$ is known to trigger ceramide accumulation. ${ }^{14} \mathrm{We}$ have recently demonstrated p53-dependent ceramide formation during etoposide-induced apoptosis of human glioma cells. $^{22}$ Therefore, changes in ceramide content following $\mathrm{TNF}-\alpha$ treatment were examined among cell lines with different p53 status. U87-LXSN and U87-M E6 cells expressing functional p53 exhibited significant ceramide accumulation (Figure 2b). However, in cells devoid of functional p53 (U87-W E6 and U-251 MG cells), TNF- $\alpha$-induced ceramide formation was suppressed in proportion to the rate of apoptosis. Similar profiles of $\left[{ }^{14} \mathrm{C}\right]$ ceramide formation with concomitant decrease in $\left[{ }^{14} \mathrm{C}\right] \mathrm{SM}$ were observed in cells labeled with $\left[{ }^{14} \mathrm{C}\right]$ serine (data not shown). Thus, functional p53 expression plays a role in ceramide accumulation, leading to significant cell death in glioma cells treated with TNF- $\alpha$.

\section{p53-dependent N-SMase activation and p53-independent A-SMase activation during TNF- $\alpha$ treatment}

Since $\mathrm{N}$ - and A-SMases are known to be involved in ceramide accumulation in response to $\mathrm{TNF}-\alpha,{ }^{17}$ changes in their activities were examined. In U87-W E6 and U-251 MG cells, significant changes were observed only in A-SMase activity (four-fold increase over the control) (Figure 2c and d). In U87LXSN and U87-M E6 cells, TNF- $\alpha$ sharply increased both 

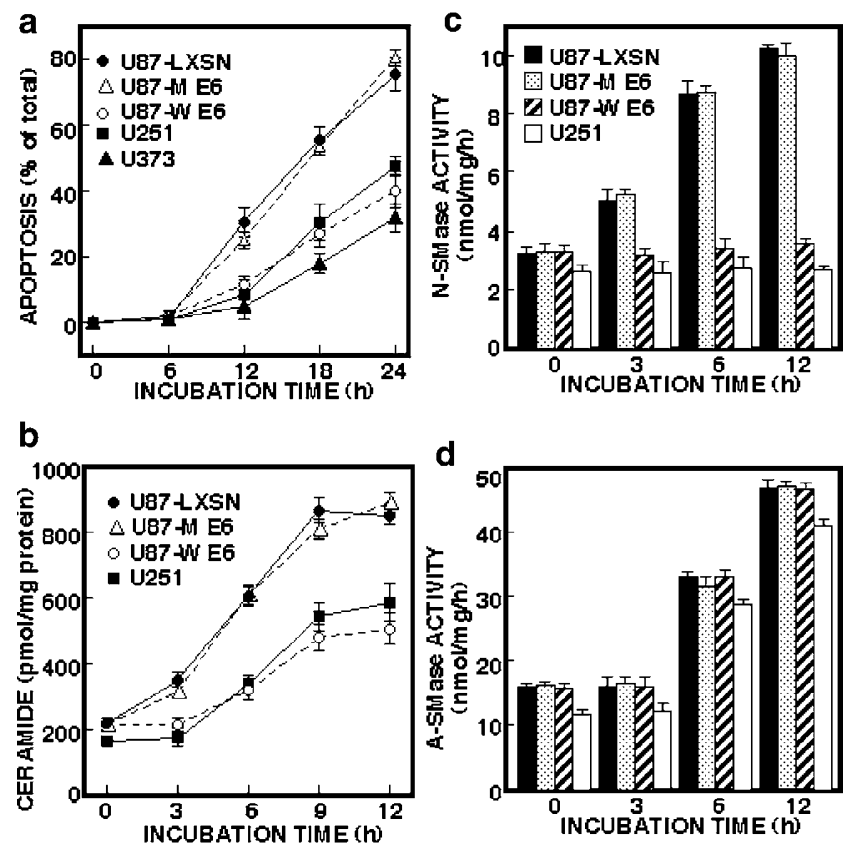

Figure 2 TNF- $\alpha$ triggers p53-dependent and -independent apoptosis, ceramide formation, and SMase activation in human glioma cells. U87-LXSN

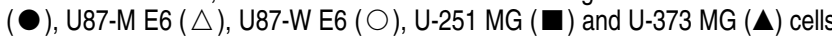
were treated with $100 \mathrm{ng} / \mathrm{ml}$ TNF- $\alpha$ plus $1 \mu \mathrm{g} / \mathrm{ml} \mathrm{CHX}$ for the indicated periods. (a) The cells with fragmented and condensed nuclei were counted in over 1000 cells under a fluorescent microscope. (b) Changes in intracellular ceramide contents. Ceramide content was measured by the $E$. coli diacylglycerol kinase assay. (c and d) The activities of N-SMase (c) and A-SMase (d) were determined using a mixed micelle assay system with $\left[\right.$ methyl- $\left.{ }^{14} \mathrm{C}\right] \mathrm{SM}$ at $\mathrm{pH} 7.5$ and 5.5 , respectively. Data are means \pm S.D. from three independent experiments, each performed in duplicate

SMase activities at $12 \mathrm{~h}$ (approximately three-fold increases over the control for each). Moreover, activation of N-SMase was detectable earlier than that of A-SMase. Activation of ASMase thus appears to be independent of functional p53, whereas N-SMase activation is likely to be dependent on functional $\mathrm{p} 53$.

In order to determine whether ceramide generated through either A-SMase or N-SMase plays a crucial role in the apoptotic process during TNF- $\alpha$ treatment, the effects of specifically inhibiting $\mathrm{N}$-SMase and A-SMase were examined using scyphostatin ${ }^{25,26}$ and ((2-isopropyl-1-(4-[3- $N$-methyl$\mathrm{N}$-(3,4-dimethoxy-beta-phenethyl)amino]propyloxy)-benzenesulfonyl))indolizine (SR33557), ${ }^{27,28}$ respectively. As shown in Figure 3a, preincubation of human glioma cells with $1 \mu \mathrm{M}$ scyphostatin or $10 \mu \mathrm{M}$ SR33557 for $1 \mathrm{~h}$ specifically inhibited the activation of N-SMase or A-SMase induced by TNF- $\alpha$, respectively, in consistent with previous reports. ${ }^{25-28}$ Throughout the inhibition of SMase activation by scyphostatin and/or SR33557, both ceramide levels and the number of apoptotic cells were significantly inhibited (Figure $3 \mathrm{~b}$ and $\mathrm{c}$ ). These findings suggest that the changes in ceramide levels and activities of SMases are not consequences of the apoptotic process triggered by TNF- $\alpha$. Moreover, to confirm the pathway of ceramide formation, we investigated the effect of fumonisin B1 (FB1), an inhibitor of sphinganine $\mathrm{N}$ acetyltransferase, which is known to inhibit de novo synthesis of ceramide. ${ }^{29,30} \mathrm{FB} 1$ at $100 \mu \mathrm{M}$ had no effect on either TNF- $\alpha$ -

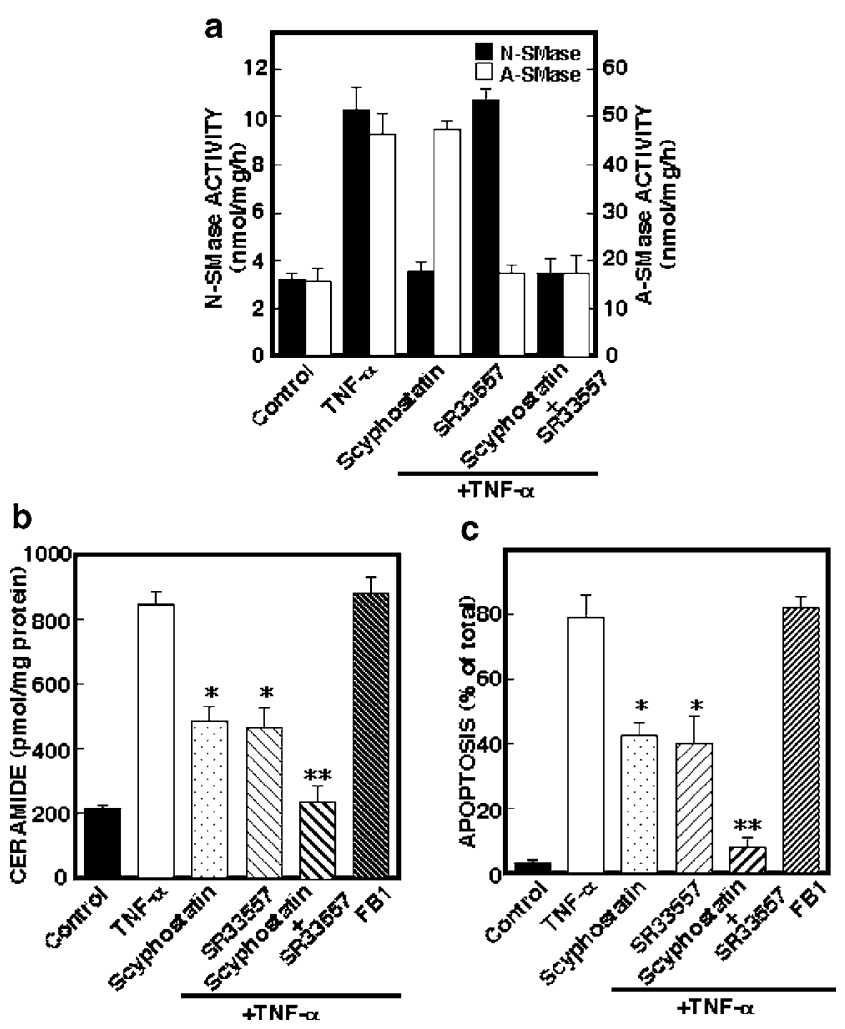

Figure 3 Effects of selective inhibitors against SMase activation. (a) U-87 MG cells were treated with $100 \mathrm{ng} / \mathrm{ml} \mathrm{TNF-} \alpha$ plus $1 \mu \mathrm{g} / \mathrm{ml} \mathrm{CHX}$ for $12 \mathrm{~h}$ in the presence or absence of $1 \mu \mathrm{M}$ scyphostatin and/or $10 \mu \mathrm{M}$ SR33557. The activities of A-SMase and N-SMase were determined using a mixed micelle assay system with [methyl- $\left.{ }^{14} \mathrm{C}\right] \mathrm{SM}$ at pH 5.5 and 7.5 , respectively. (b) U-87 MG cells were treated with $100 \mathrm{ng} / \mathrm{ml} \mathrm{TNF-} \alpha$ plus $1 \mu \mathrm{g} / \mathrm{ml} \mathrm{CHX}$ for $12 \mathrm{~h}$ in the presence or absence of $1 \mu \mathrm{M}$ scyphostatin, $10 \mu \mathrm{M}$ SR33557, or $100 \mu \mathrm{M}$ FB1. Ceramide content was measured by the $E$. coli diacylglycerol kinase assay. (c) U-87 MG cells were treated with $100 \mathrm{ng} / \mathrm{ml} \mathrm{TNF-} \alpha$ plus $1 \mu \mathrm{g} / \mathrm{ml} \mathrm{CHX}$ for $24 \mathrm{~h}$ in the presence or absence of $1 \mu \mathrm{M}$ scyphostatin, $10 \mu \mathrm{M}$ SR33557, or $100 \mu \mathrm{M}$ FB1. The cells with fragmented and condensed nuclei were counted in over 1000 cells under a fluorescent microscope. Data are means \pm S.D. from three independent experiments, each performed in duplicate. ${ }^{*} P<0.05$ and ${ }^{* *} P<0.01$ versus TNF$\alpha$ alone: two-way ANOVA followed by Scheffe's post hoc test

induced accumulation of ceramide or increase in the number of apoptotic cells (Figure $3 b$ and $c$ ). These findings indicate that ceramide is produced by SM hydrolysis, but not by de novo synthesis, during TNF- $\alpha$-induced apoptosis.

\section{p53-dependent pathway is mediated by ROS}

ROS, including $\mathrm{O}_{2}^{-\bullet}, \mathrm{H}_{2} \mathrm{O}_{2}$, and ${ }^{\bullet} \mathrm{OH}$, are known to function as signaling molecules in response to TNF- $\alpha .{ }^{1-4}$ However, none of the antioxidants tested, Tiron or superoxide dismutase (SOD) for $\mathrm{O}_{2}^{-\bullet}$, catalase for $\mathrm{H}_{2} \mathrm{O}_{2}$, and sodium formate for - $\mathrm{OH}$, had any effects on TNF- $\alpha$-induced apoptosis in U87-W E6 and U-251 MG cells (Table 1). Although $100 \mathrm{mM}$ sodium formate failed to affect TNF- $\alpha$-induced apoptosis, catalase $(10000 \mathrm{U} / \mathrm{ml})$ and $5 \mathrm{mM}$ Tiron or $1000 \mathrm{U} / \mathrm{ml}$ SOD exhibited protective effects against TNF- $\alpha$-induced apoptosis in U-87 MG cells (Figure 4a). Notably, even in the presence of effective amounts of antioxidants such as Tiron or SOD, nearly half of U-87 MG cells underwent apoptosis. These findings suggest that two separate signaling cascades are 
Table 1 Effects of antioxidants on TNF- $\alpha$-induced apoptosis, SMase activation, and ceramide formation

\begin{tabular}{|c|c|c|c|c|}
\hline Cells/treatment & $\begin{array}{l}\text { Apoptosis } \\
\text { (\% of total) }\end{array}$ & $\begin{array}{c}\text { N-SMase } \\
\text { (nmol/mg/h) }\end{array}$ & $\begin{array}{c}\text { A-SMage } \\
\text { (nmol/mg/h) }\end{array}$ & $\begin{array}{l}\text { Ceramide formation } \\
\text { (pmol/mg protein) }\end{array}$ \\
\hline U87-LXSN + none (control) & 3 & 3.2 & 15.8 & 212 \\
\hline+ TNF- $\alpha$ & $81^{*}$ & $10.2^{*}$ & $45.9^{*}$ & $862^{*}$ \\
\hline+ TNF- $\alpha+$ SOD $(1000 \mathrm{U} / \mathrm{ml})$ & $46^{\star \star}$ & $3.9^{\star *}$ & 45.1 & $559^{\star \star}$ \\
\hline+ TNF- $\alpha+$ Tiron $(5 \mathrm{mM})$ & $39^{\star \star}$ & $3.4^{\star *}$ & 46.9 & $516^{\star *}$ \\
\hline U87-W E6 + None (Control) & 2 & 3.1 & 15.2 & 208 \\
\hline+ TNF- $\alpha$ & $38^{*}$ & 3.3 & $46.5^{\star}$ & $515^{\star}$ \\
\hline+ TNF- $\alpha+$ SOD $(1000 \mathrm{U} / \mathrm{ml})$ & 41 & 3.4 & 46.5 & 519 \\
\hline + TNF- $\alpha+$ Tiron (5 mM) & 39 & 3.2 & 46.1 & 522 \\
\hline U251-MG + None (control) & 2 & 2.5 & 11.7 & 168 \\
\hline+ TNF- $\alpha$ & $44^{*}$ & 2.4 & $39.9^{\star}$ & 571 \\
\hline+ TNF- $\alpha+$ SOD $(1000 \mathrm{U} / \mathrm{ml})$ & 42 & 2.8 & 39.4 & 582 \\
\hline+ TNF- $\alpha+$ Tiron $(5 \mathrm{mM})$ & 45 & 2.7 & 39.0 & 595 \\
\hline
\end{tabular}

U87-LXSN, U87-W E6, and U-251 MG cells were treated with $100 \mathrm{ng} / \mathrm{ml} \mathrm{TNF-} \alpha$ plus $1 \mu \mathrm{g} / \mathrm{ml} \mathrm{CHX} \mathrm{in} \mathrm{the} \mathrm{presence} \mathrm{or} \mathrm{absence} \mathrm{of} 1000 \mathrm{U} / \mathrm{ml} \mathrm{SOD}$ or $5 \mathrm{mM} \mathrm{Tiron} \mathrm{for} 24 \mathrm{~h}$. ${ }^{\star} P<0.01$ versus control. ${ }^{\star *} P<0.01$ versus TNF- $\alpha$ alone.

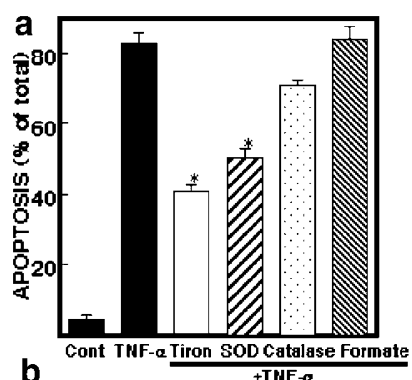

b
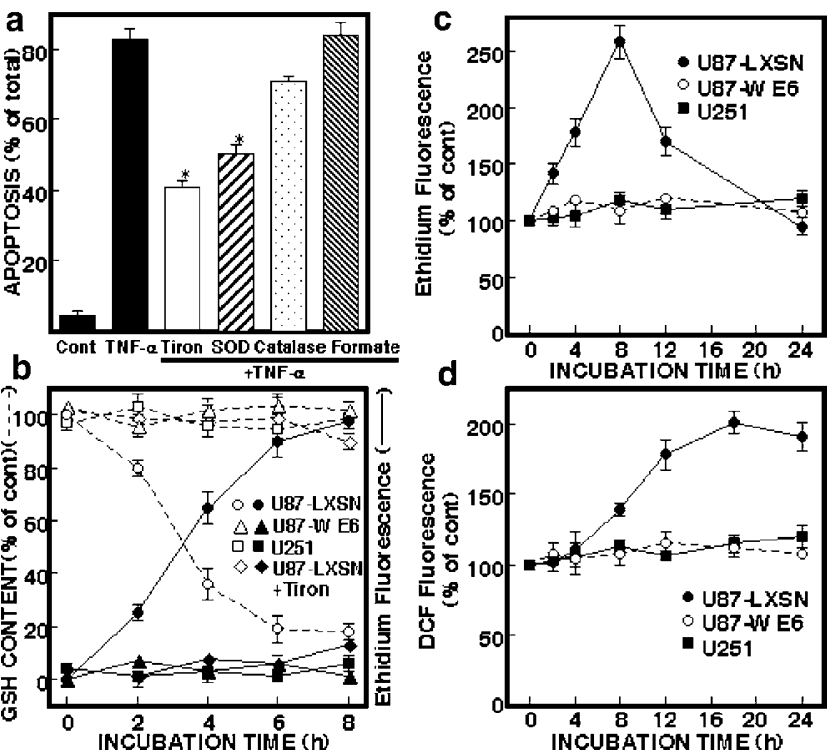

Figure 4 ROS formation and the effects of antioxidants during TNF- $\alpha$-induced apoptosis. U-87 MG cells were preincubated with $5 \mathrm{mM}$ Tiron, $1000 \mathrm{U} / \mathrm{ml} \mathrm{SOD}$, $10000 \mathrm{U} / \mathrm{ml}$ catalase, or $100 \mathrm{mM}$ sodium formate for $24 \mathrm{~h}$ and then exposed to $100 \mathrm{ng} / \mathrm{ml}$ TNF- $\alpha$ plus $1 \mu \mathrm{g} / \mathrm{ml} \mathrm{CHX}$ for $24 \mathrm{~h}$. (a) The cells with fragmented and condensed nuclei were counted in over 1000 cells under a fluorescent microscope. ${ }^{*} P<0.01$ versus TNF- $\alpha$ alone. (b) Time-dependent changes in intracellular GSH level $(O, \triangle, \square, \diamond)$ and $\mathrm{O}_{2}^{-} \bullet$ formation $(\bullet, \triangle, \bullet)$ measured by ethidium fluorescence. GSH content and ethidium fluorescence were presented as a percentage of the values obtained in untreated control cells (Time 0). U87-LXSN $(\bigcirc, \boldsymbol{O})$, U87-Wild E6 $(\triangle, \boldsymbol{\Delta}), \mathrm{U}-251 \mathrm{MG}(\square, \boldsymbol{\square})$ and U87-LXSN cells pretreated with Tiron $(\diamond, \diamond)$ were exposed to $100 \mathrm{ng} / \mathrm{ml}$ TNF- $\alpha$ plus $1 \mu \mathrm{g} / \mathrm{ml} \mathrm{CHX}$ for the indicated periods. (c and d) U87-LXSN (-), U87-W E6 (O), and U-251 MG (ם) cells were exposed to $100 \mathrm{ng} / \mathrm{ml} \mathrm{TNF-} \alpha$ plus $1 \mu \mathrm{g} / \mathrm{ml}$ $\mathrm{CHX}$ for the indicated periods. ROS production was detected with $\mathrm{HE}$ selective for $\mathrm{O}_{2}^{-\bullet}$ or DCFH-DA (d) selective for $\mathrm{H}_{2} \mathrm{O}_{2}$. Data are means \pm S.D. from three independent experiments, each performed in duplicate

activated by TNF- $\alpha$ in U-87 MG cells, one ROS dependent and the other ROS independent.

Intracellular ROS production in TNF- $\alpha$-triggered human glioma cells was measured by staining these cells with ROSsensitive fluorescent dyes hydroethidium (HE) and $2^{\prime}, 7^{\prime}$ dichlorofluorescein diacetate (DCFH-DA) ${ }^{22}$ to confirm the effects of antioxidants. Consistent with the failure of anti-

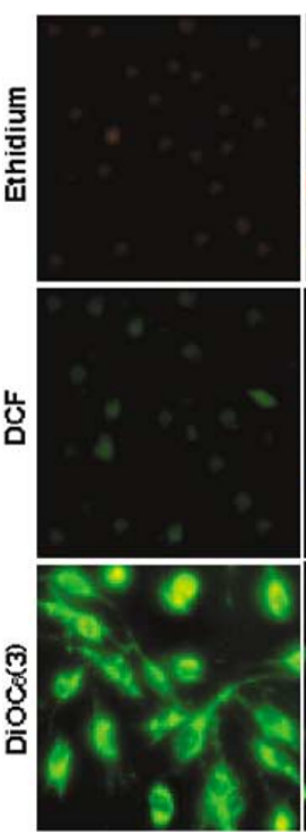

Control
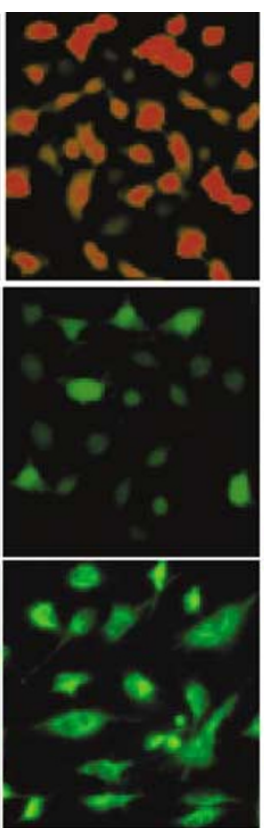

TNF 8h

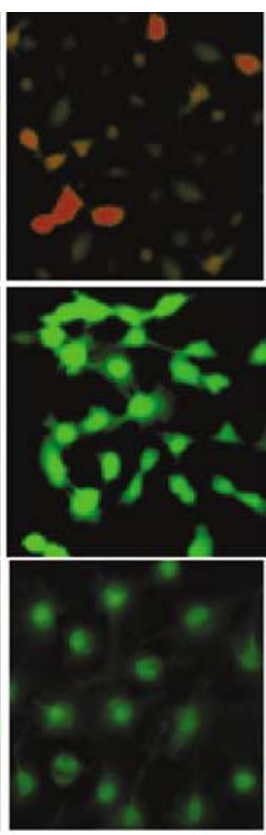

TNF 16h
Figure 5 Visualization of TNF- $\alpha$-induced formation of ROS and alteration of $\Delta \psi_{\mathrm{m}}$ in U-87 MG cells. U-87 MG cells were treated with $100 \mathrm{ng} / \mathrm{ml}$ TNF- $\alpha$ plus $1 \mu \mathrm{g} / \mathrm{ml} \mathrm{CHX}$ for the indicated periods and compared with untreated control cells using a fluorescent microscopy. ROS production visualized by staining with $\mathrm{HE}$ (upper) or DCFH-DA (middle). Mitochondrial network visualized by staining with $\mathrm{DiOC}_{6}(3)$ (lower). Photographs were taken with a fluorescent microscope and are representatives of at least 10 different cultures

oxidants to inhibit TNF- $\alpha$-induced apoptosis, significant increases in neither ethidium nor $2^{\prime}, 7^{\prime}$-dichlorofluorescein (DCF) fluorescence were observed in U87-W E6 and U-251 MG cells during the time course examined (Figure $4 c$ and $d$ ). As expected, in U87-LXSN cells, TNF- $\alpha$ sharply and transiently increased intracellular $\mathrm{O}_{2}^{-}$, with a peak at $8 \mathrm{~h}$, as assessed by $\mathrm{HE}$, followed by a gradual decrease (Figure 4c). Also, in U87-LXSN cells, $\mathrm{H}_{2} \mathrm{O}_{2}$, as detected by DCFH-DA, began to increase at $8 \mathrm{~h}$ and peaked at $18 \mathrm{~h}$ (Figure $4 \mathrm{~d}$ ). Similar profiles of ROS production were visualized on a fluorescence microscopy (Figure 5). 
As shown in Table 1, TNF- $\alpha$-induced A-SMase activation and the resulting ceramide formation were affected by neither Tiron nor SOD in glioma cells regardless of their p53 status. In contrast, N-SMase activation in U87-LXSN cells was nearly abolished by these antioxidants. In U87-LXSN cells, the depletion of reduced glutathione (GSH) correlated well with the production of $\mathrm{O}_{2}^{-\bullet}$ measured by the fluorescent dye $\mathrm{HE}$, and pretreatment with Tiron prior to TNF- $\alpha$ significantly reduced GSH depletion (Figure 4b). The addition of an $\mathrm{O}_{2}^{-\bullet}$-releasing agent, pyrogallol, ${ }^{22,31,32}$ decreased $\mathrm{GSH}$ levels in U-87 MG cells, although this change was prevented to a significant extent by pretreatment with Tiron (data not shown). These results indicate that p53-mediated $\mathrm{O}_{2}^{-\bullet}$ production is responsible for GSH depletion, leading to ceramide formation through $\mathrm{N}$-SMase activation during TNF- $\alpha$ treatment.

\section{Mtp53ts sensitizes cells with mutant p53 to TNF- $\alpha$-induced $\mathrm{O}_{2}^{-}$production}

The involvement of ROS in p53-mediated TNF- $\alpha$-induced apoptosis was further examined in U-373 MG and U-251 MG cells transfected with an expression plasmid encoding temperature-sensitive human p53 val ${ }^{138}$ mutant (MTp53ts), which assumes mutant conformation at $37.5^{\circ} \mathrm{C}$ and wild-type conformation at $32.5^{\circ} \mathrm{C}^{33,34}$ At $32.5^{\circ} \mathrm{C}$, MTp53ts caused DNA fragmentation and yielded classical apoptotic morphological features through the formation of $\mathrm{O}_{2}^{-\bullet}$ in U-373 MG cells, as described previously. ${ }^{22}$ MTp53ts also sensitized U-373 MG cells to TNF- $\alpha$-induced cytotoxity (Figure 6a), with increased production of $\mathrm{O}_{2}^{-\bullet}$ as assessed by $\mathrm{HE}$ (Figure 6b). Tiron nearly abolished $\mathrm{O}_{2}^{-} \bullet$ production by TNF- $\alpha$ in U-373 MG cells expressing Mtp53ts and significantly prevented the cytotoxic effect of TNF- $\alpha$. These findings strongly suggest that functional p53 sensitizes human glioma cells, less sensitive to TNF- $\alpha$ due to mutant p53, to TNF- $\alpha$-induced apoptosis by a pathway that is dependent on $\mathrm{O}_{2}^{-\bullet}$ production. Similar findings were observed for U-251 MG cells transfected with MTp53ts (data not shown).

\section{Mitochondria are involved in both ROS-dependent and -independent signaling pathways}

To examine the involvement of the mitochondrial pathway in TNF- $\alpha$-mediated apoptosis, alterations of mitochondrial transmembrane potential $\left(\Delta \psi_{\mathrm{m}}\right)$ using 3,3'-dihexyloxacarbocyanine iodide $\left(\mathrm{DiOC}_{6}(3)\right)$ as a fluorochrome ${ }^{35,36}$ as well as release of cytochrome $c$ were examined. A sharp decrease in $\Delta \psi_{\mathrm{m}}$ was detectable at $8 \mathrm{~h}$ following TNF- $\alpha$ treatment in U87-LXSN cells. The minimum level was obtained at $16 \mathrm{~h}$ and sustained to $24 \mathrm{~h}$ (Figure $7 \mathrm{a}$ ). Similar results were confirmed by fluorescence microscopy (Figure 5). In contrast, the decrease of $\Delta \psi_{\mathrm{m}}$ in U87-W E6 and U-251 MG cells was about half that seen in U87-LXSN cells (Figure 7a and b). Moreover, antioxidants suppressed the decrease of $\Delta \psi_{\mathrm{m}}$ in U87-LXSN cells to nearly the same level as in U87-W E6 cells. The involvement of mitochondria in the TNF- $\alpha$-induced apoptotic pathway was further examined by determining

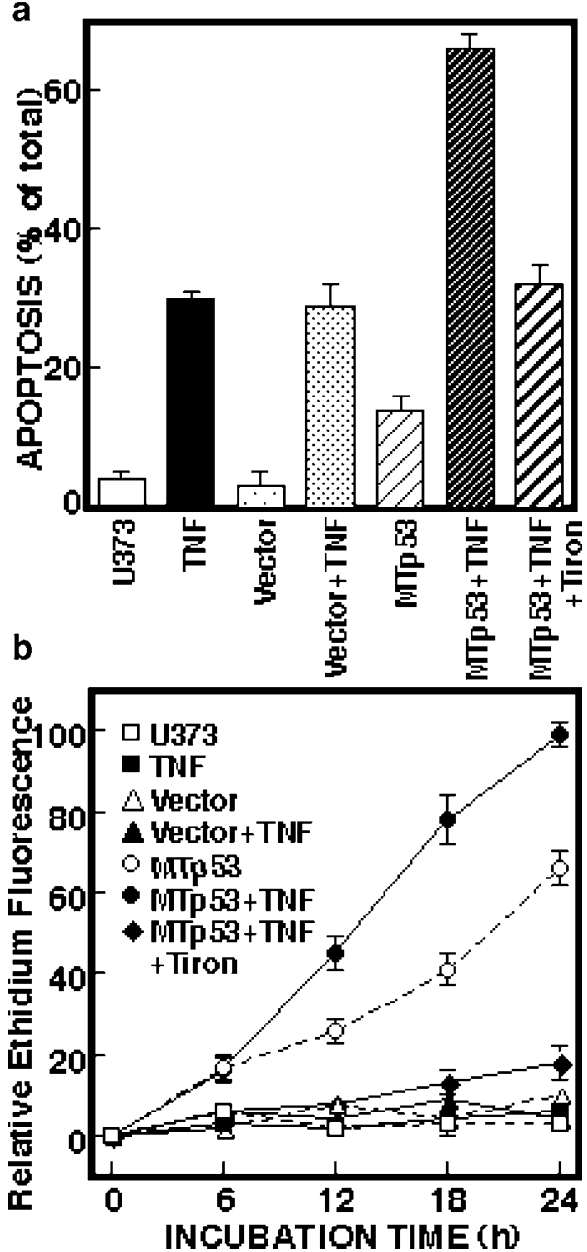

Figure 6 MTp53ts sensitizes U-373 MG cells to TNF- $\alpha$-mediated cytotoxicity by increasing $\mathrm{O}_{2}^{-}$production. (a) U-373 MG cells transfected with empty vector (Vector) or temperature-sensitive mutant p53 vector (MTp53) were treated with $100 \mathrm{ng} / \mathrm{ml} \mathrm{TNF}-\alpha$ plus $1 \mu \mathrm{g} / \mathrm{ml} \mathrm{CHX}$ in the presence or absence of $5 \mathrm{mM}$ Tiron under inducing condition $\left(32.5^{\circ} \mathrm{C}\right.$ ) for $24 \mathrm{~h}$. (b) Time-dependent changes in $\mathrm{O}_{2}^{-}$ formation measured by ethidium fluorescence. Ethidium fluorescence of untreated control cells (time 0 ) and that of MTp53ts-transfected U-373 MG cells treated with $100 \mathrm{ng} / \mathrm{ml} \mathrm{TNF}-\alpha$ plus $1 \mu \mathrm{g} / \mathrm{ml} \mathrm{CHX}$ for $24 \mathrm{~h}$ were designed as 0 and $100 \%$, respectively. Data are means \pm S.D. from three independent experiments, each performed in duplicate

the release of cytochrome $c$ from mitochondria to cytosol. Cytosolic cytochrome $c$ release was first detected at $8 \mathrm{~h}$ following TNF- $\alpha$ treatment in U87-LXSN cells (Figure 7c). Tiron delayed the release of cytochrome $c$ into cytosol. In U87-W E6 and U-251 MG cells, cytochrome $c$ release in response to TNF- $\alpha$ was delayed and became evident at $16 \mathrm{~h}$. Cytochrome $c$ release in response to TNF- $\alpha$ was eliminated by benzyloxycarbonyl-Ile-Glu-Thr-Asp fluoromethyl ketone (z-IETD-fmk), a selective inhibitor for caspase-8. In contrast, benzyloxycarbonyl-Asp-Glu-Val-Asp fluoromethyl ketone (z-DEVD-fmk), a selective inhibitor for caspase-3, had no effect. Taken together, these observations suggest that mitochondria are involved in the ROS-independent signaling cascade as well as the ROS-dependent pathway downstream of caspase-8. 

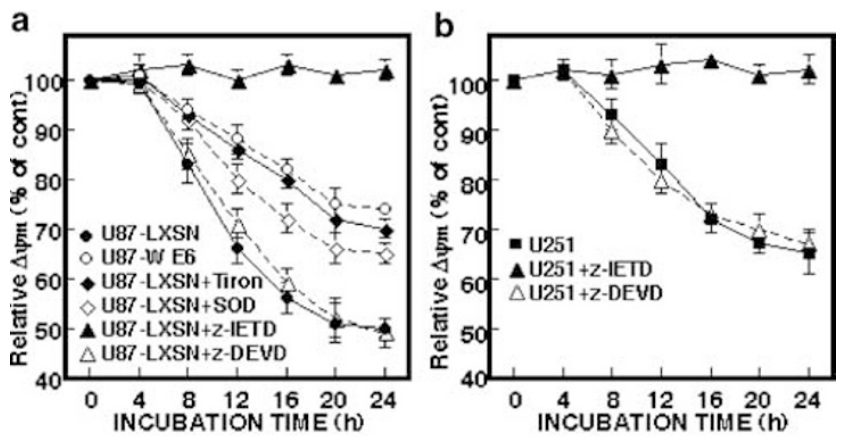

C

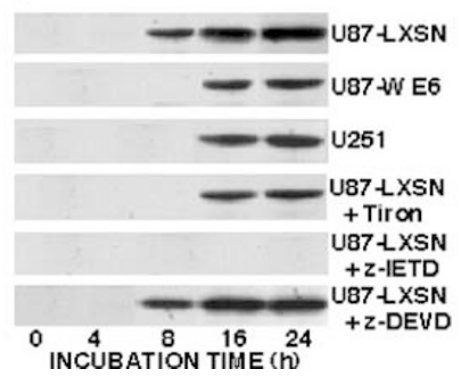

Figure 7 TNF- $\alpha$-induced alteration of $\Delta \psi_{\mathrm{m}}$ and cytochrome $c$ release. (a) U87$\operatorname{LXSN}(-)$, U87-W E6 (O), U87-LXSN cells pretreated for $24 \mathrm{~h}$ with $5 \mathrm{mM}$ Tiron $(\diamond)$ or $1000 \mathrm{U} / \mathrm{ml} \mathrm{SOD}(\diamond)$, and U87-LXSN cells in the presence of $200 \mu \mathrm{M} \mathrm{z}$ IETD-fmk $(\boldsymbol{\Delta})$, or $200 \mu \mathrm{M}$ z-DEVD-fmk $(\triangle)$ were treated with TNF- $\alpha$ for the indicated periods and then $\Delta \psi_{m}$ was detected by staining with $\mathrm{DiOC}_{6}(3)$. (b) $\mathrm{U}$ $251 \mathrm{MG}(\boldsymbol{\square})$ and U-251 MG in the presence of Z-IETD-fmk $(\boldsymbol{\Delta})$ or Z-DEVD-fmk $(\triangle)$ were treated with TNF- $\alpha$ for the indicated periods and $\Delta \psi_{\mathrm{m}}$ was detected by staining with $\mathrm{DiOC}_{6}(3)$. Data are means \pm S.D. from three independent experiments, each performed in duplicate. (c) U87-LXSN, U87-W E6, U-251 MG, U87-LXSN cells pretreated for $24 \mathrm{~h}$ with $5 \mathrm{mM}$ Tiron, and U87-LXSN cells in the presence of $200 \mu \mathrm{M}$ z-IETD-fmk or $200 \mu \mathrm{M} z$-DEVD-fmk were treated with TNF- $\alpha$ for the indicated periods. The cytosolic extracts were prepared and cytochrome $c$ release was examined by immunoblot analysis. Data shown are representative of three separate experiments with compatible outcomes

\section{Two types of TNF- $\alpha$-induced signaling are initiated downstream of caspase-8}

In the TNF- $\alpha$-induced cell death signaling cascade, caspase- 8 appears to function as an upstream component leading to the activation of executor caspase-3 or $-7 .{ }^{37,38}$ The processing of caspase-8 (degradation of procaspase- 8 and appearance of active caspase-8) proceeded to nearly equal extents in U87LXSN and U87-W E6 cells regardless of the p53 status
(Figure $8 \mathrm{a}$ and b). Antioxidants had no effects on TNF- $\alpha$ induced activation of caspase-8 in U87-LXSN cells. Z-IETDfmk effectively inhibited ceramide formation with abolishment of both $\mathrm{N}$ - and A-SMase activation (Table 2), ROS production, and decrease in $\Delta \psi_{\mathrm{m}}$ (Figure $7 \mathrm{a}$ and $\mathrm{b}$ ). On the other hand, $\mathrm{z}$ DEVD-fmk had no effects on ROS production and loss of $\Delta \psi_{\mathrm{m}}$ (Figure $7 \mathrm{a}$ and $\mathrm{b}$ ), although it protected cells from TNF- $\alpha$ induced apoptosis (Table 2). Caspase-8 thus functions as an apical caspase and caspase-3 as an executor caspase. Moreover, p53 accumulation in response to TNF- $\alpha$ treatment in U87-LXSN cells was abrogated by z-IETD-fmk, but not by zDEVD-fmk (Figure 8c). These results indicate that caspase-8 is upstream of p53 and p53 is located between caspase-8 and -3 .

Since it has recently been reported that a lysosomal cystein protease, cathepsin B, is involved in TNF- $\alpha$-induced cell death, ${ }^{39,40}$ we examined the effect of a specific inhibitor of cathepsin B, [L-3-trans-(propylcarbamoyl)oxirane-2-carbonyl]-L-isoleucyl-L-proline methyl ester (CA074 Me), ${ }^{41}$ on TNF- $\alpha$-induced cell death of human glioma cells. As shown in Figure $9 \mathrm{a}, 50 \mu \mathrm{M}$ CA074 Me had no effects on TNF- $\alpha$ induced apoptosis in human glioma cells. In addition, it has been reported that pretreatment with a vacuolar $\mathrm{H}^{+}$-ATPase inhibitor, Bafilomycin $\mathrm{A} 1,{ }^{42}$ increases lysosomal $\mathrm{pH}$, resulting in the degradation of lysosomal proteinases including cathepsin B. We next investigated the effect of Bafilomycin $\mathrm{A} 1$, and observed that $12 \mathrm{~h}$ pretreatment with $10 \mathrm{nM}$ Bafilomycin A1 did not affect TNF- $\alpha$-induced apoptosis in human glioma cells (Figure 9a). These results suggest that cathepsin $B$ is not involved in TNF- $\alpha$-induced apoptosis in human glioma cells.

Furthermore, it is known that cathepsin $B$ is synthesized as a proenzyme and is transported into lysosomes where it is processed into active forms, a two-chain form (25-27 kDa) and single-chain form (29-31 kDa), by lysosomal cysteine proteinases. ${ }^{42,43}$ Therefore, we further examined whether TNF- $\alpha$ can increase the amount of cathepsin B or induce the release of cathepsin $B$ from lysosome to cytosol in human glioma cells. As shown in Figure 9b, we observed only the single-chain form of cathepsin B in whole-cell lysate of U-87 MG cells. However, this active form of cathepsin B could not be released into cytosol during TNF- $\alpha$-induced cell death. Collectively, these results indicate that TNF- $\alpha$-induced apoptosis is not mediated by cathepsin B in human glioma cells.

Table 2 Effects of caspase inhibitors on TNF- $\alpha$-induced apoptosis, SMase activation, and ceramide formation

\begin{tabular}{|c|c|c|c|c|}
\hline Cells/treatment & $\begin{array}{l}\text { Apoptosis } \\
\text { (\% of total) }\end{array}$ & $\begin{array}{c}\text { N-SMase } \\
\text { (nmol/mg/h) }\end{array}$ & $\begin{array}{c}\text { A-SMage } \\
\text { (nmol/mg/h) }\end{array}$ & $\begin{array}{l}\text { Ceramide formation } \\
\text { (pmol/mg protein) }\end{array}$ \\
\hline U-87 MG (control) & 3 & 3.1 & 15.8 & 212 \\
\hline $\mathrm{U}-87 \mathrm{MG}+\mathrm{TNF}-\alpha$ & $82^{\star}$ & $10.2^{*}$ & $45.9^{\star}$ & $862^{*}$ \\
\hline U-87 MG + TNF- $\alpha+z-I E T D$ & $8^{\star \star}$ & $3.2^{\star \star}$ & $16.5^{\star \star}$ & $215^{\star \star}$ \\
\hline U-87 MG + TNF- $\alpha+z-D E V D$ & $7^{\star \star}$ & 10.8 & 46.8 & 873 \\
\hline U-251 MG (control) & 2 & 2.4 & 11.5 & 169 \\
\hline$U-251 M G+T N F-\alpha$ & $42^{*}$ & 2.6 & $42.1^{*}$ & $592^{*}$ \\
\hline U-251 MG + TNF- $\alpha+z$-IETD & $6^{\star *}$ & 2.7 & $12.0^{\star *}$ & $175^{\star \star}$ \\
\hline $\mathrm{U}-251 \mathrm{MG}+\mathrm{TNF}-\alpha+\mathrm{z}-\mathrm{DEVD}$ & $5^{\star \star}$ & 2.6 & 43.2 & 575 \\
\hline
\end{tabular}

U-87 MG and U-251 MG cells were treated with $100 \mathrm{ng} / \mathrm{ml} \mathrm{TNF}-\alpha$ plus $1 \mu \mathrm{g} / \mathrm{ml} \mathrm{CHX} \mathrm{in} \mathrm{the} \mathrm{presence} \mathrm{or} \mathrm{absence} \mathrm{of} \mathrm{z-IETD.fmk} \mathrm{or} \mathrm{z-DEVD.fmk} \mathrm{for} 24 \mathrm{~h} .{ }^{*} P<0.01 \mathrm{versus}$ control. ${ }^{* \star} P<0.01$ versus TNF- $\alpha$ alone. 


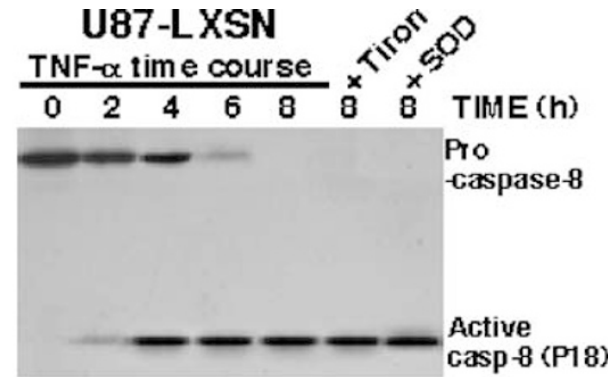

b

TNF-a time course
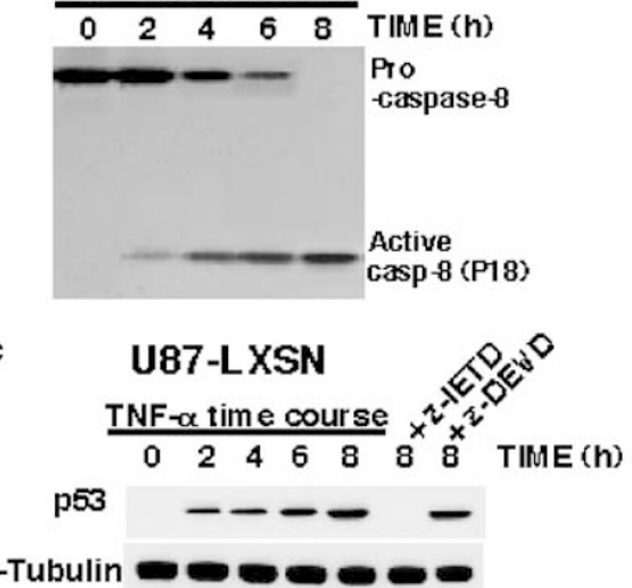

Figure 8 TNF- $\alpha$-triggered processing of caspase-8 in a p53-independent manner. (a) U87-LXSN cells were exposed to $100 \mathrm{ng} / \mathrm{ml} \mathrm{TNF-} \alpha$ plus $1 \mu \mathrm{g} / \mathrm{ml} \mathrm{CHX}$ for the indicated periods in the absence or presence of $5 \mathrm{mM}$ Tiron or $1000 \mathrm{U} / \mathrm{ml}$ SOD. (b) U87-W E6 cells were treated with $100 \mathrm{ng} / \mathrm{ml} \mathrm{TNF-} \alpha$ plus $1 \mu \mathrm{g} / \mathrm{ml} \mathrm{CHX}$ for the indicated periods. Cellular proteins were subjected to SDS-PAGE and immunoblotted with antibody against caspase-8. (c) U87-LXSN cells were exposed to $100 \mathrm{ng} / \mathrm{ml} \mathrm{TNF}-\alpha$ plus $1 \mu \mathrm{g} / \mathrm{ml} \mathrm{CHX}$ for the indicated periods in the absence or presence of $200 \mu \mathrm{M}$ z-IETD-fmk or $200 \mu \mathrm{M}$ z-DEVD-fmk. Cellula proteins were subjected to SDS-PAGE and immunoblotted with antibodies against p53 and $\beta$-tubulin. Data shown are representative of three separate experiments with compatible outcomes

\section{Depletion of functional p53 by retroviral infection of short hairpin RNA (shRNA) inhibits TNF- $\alpha$ - induced ceramide formation and apoptosis}

Accumulation of $p 53$ and p53-dependent proteins such as p21 and Bax during TNF- $\alpha$ signaling was abrogated in U-87 MG cells infected with retrovirus expressing p53 shRNA (U87p53shRNA) compared to backbone vector (U87-vector) (Figure 10a). These results indicate retroviral expression of p53 shRNA definitely inactivated functional p53. In agreement with the results obtained from disruption of functional p53 by HPV-16 E6 retroviral infection, we observed differences in the sensitivity to TNF- $\alpha$ cytotoxity between U87-vector and U87p53shRNA cells (Figure 10b-e). In U87-vector cells possessing wild-type $p 53$, TNF- $\alpha$ stimulated ceramide formation via the activation of both $\mathrm{N}$ - and $\mathrm{A}-\mathrm{SMases}$, leading to apoptotic cell death. On the other hand, p53-deficient U87-p53shRNA cells were partially resistant to TNF- $\alpha$ and lacked ceramide formation through the activation of $\mathrm{N}$-SMase but not $\mathrm{A}$ SMase. a

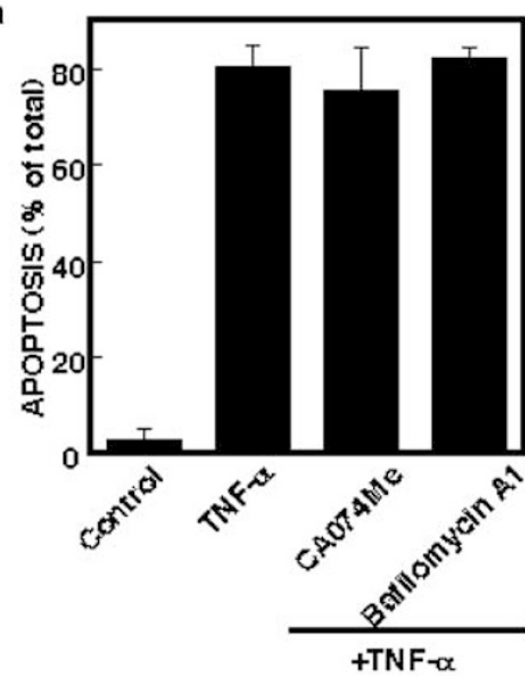

b

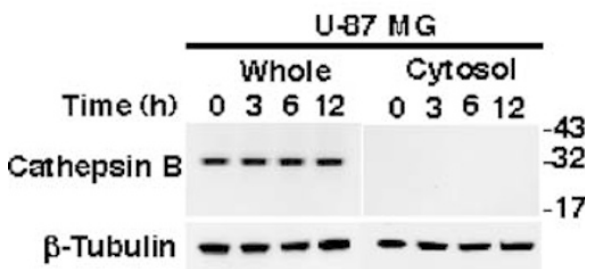

Figure 9 Cathepsin B is not involved in TNF- $\alpha$-induced apoptosis in human glioma cells. (a) U-87 MG cells were treated with $100 \mathrm{ng} / \mathrm{ml} \mathrm{TNF}-\alpha$ plus $1 \mu \mathrm{g} / \mathrm{ml}$ $\mathrm{CHX}$ in the presence or absence of $50 \mu \mathrm{M}$ CA074 Me and $10 \mathrm{nM}$ Bafilomycin A1 for $24 \mathrm{~h}$. The cells with fragmented and condensed nuclei were counted in over 1000 cells under a fluorescent microscope. Data are means \pm S.D. from three independent experiments, each performed in duplicate. (b) U-87 MG cells were treated with $100 \mathrm{ng} / \mathrm{ml} \mathrm{TNF}-\alpha$ plus $1 \mu \mathrm{g} / \mathrm{ml} \mathrm{CHX}$ for the indicated periods. Wholecell lysate and cytosolic fraction were subjected to SDS-PAGE and immunoblotted with antibodies against cathepsin B and $\beta$-tubulin. Data are representative of three separate experiments with compatible outcomes

\section{Discussion}

TNF- $\alpha$ has been shown to induce accumulation of p53 in various types of cells, suggesting the possibility of involvement of p53 in TNF- $\alpha$-induced cell death. The relationship between functional p53 and susceptibility to the cytotoxic effect of TNF- $\alpha$ has been previously observed in ovarian cancer cells, ${ }^{6} \mathrm{C} 6$ rat glioma cells, ${ }^{7}$ breast cancer cells, ${ }^{8} \mathrm{ME}$ 180 cells, ${ }^{9}$ and prostatic cancer cells. ${ }^{10}$ Consistent with these observations, our results demonstrated that disruption of functional p53 in human glioma cells by p53 shRNA as well as HPV16 E6 protein results in the decrease in the cytotoxic activity of TNF- $\alpha$. However, it should be noted that even in human glioma cells devoid of functional p53, TNF- $\alpha$ efficiently induced apoptosis, suggesting that the p53-independent death pathway is activated by TNF- $\alpha$ in human glioma cells in addition to the p53-dependent one. The partial resistance of p53-deficient glioma cells to TNF- $\alpha$-induced apoptosis correlated well with the amount of ceramide accumulation. It has been shown that p53-mediated apoptosis induced by genotoxic stress is accompanied by ceramide formation. ${ }^{22,44}$ In TNF- $\alpha$-stimulated human glioma cells, the p53-mediated signaling cascade was mediated through ceramide formation 
a

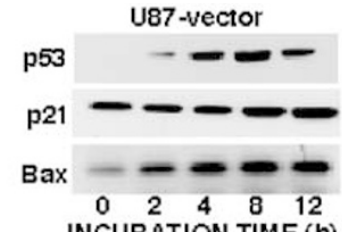

INCUBATION TIME (h)

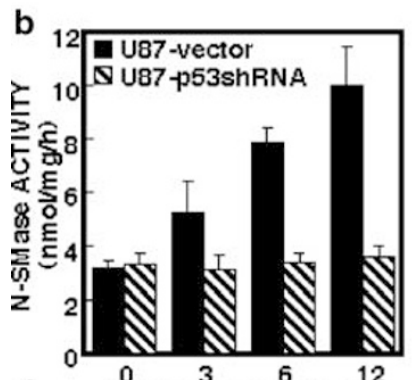

d INCUBATION TIME $(2)$

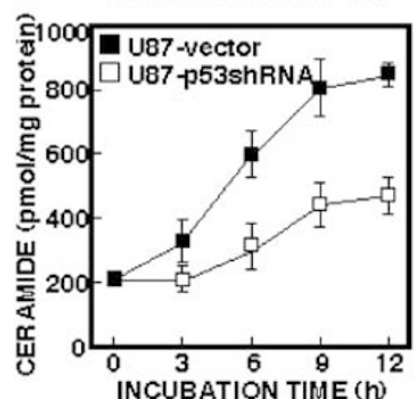

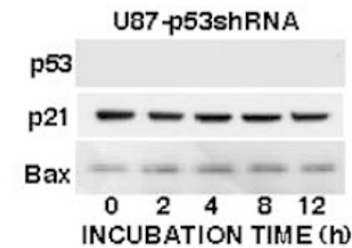
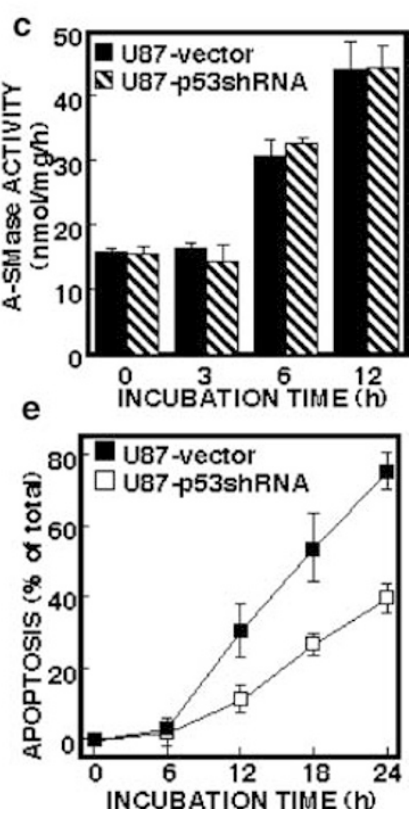

Figure 10 Depletion of functional p53 by p53 shRNA retroviral infection inhibits TNF- $\alpha$-induced apoptosis and ceramide generation. Comparison was performed between U-87 MG cells transduced with SI-MSCVpuro-H1R-p53Ri (designed as U87-p53shRNA) and SI-MSCVpuro-H1R (U87-vector). These cells possessing different p53 status were treated with $100 \mathrm{ng} / \mathrm{ml}$ TNF- $\alpha$ plus $1 \mu \mathrm{g} / \mathrm{ml} \mathrm{CHX}$ for indicated periods. (a) Cellular proteins were subjected to SDS-PAGE and immunoblotted with antibodies against p53, Bax, and p21. Data are representative of three separate experiments with compatible outcomes. (b and $\mathbf{c}$ ) The activities of $\mathrm{N}$-SMase (b) and A-SMase (c) were determined using a mixed micelle assay system with [methyl- $\left.{ }^{14} \mathrm{C}\right] \mathrm{SM}$ at $\mathrm{pH} 7.5$ and 5.5 , respectively. (d) Changes in intracellular ceramide contents. Ceramide content was measured by the $E$. coli diacylglycerol kinase assay. (e) The cells with fragmented and condensed nuclei were counted in over 1000 cells under a fluorescent microscope. Data are means \pm S.D. from three independent experiments, each performed in duplicate

by the activation of $\mathrm{N}-\mathrm{SMase}$, whereas the p53-independent pathway was associated with A-SMase.

Accumulating evidence suggests a role for ROS as mediators of p53-dependent apoptosis. ${ }^{11-13,22}$ TNF- $\alpha$ is known to induce production of ROS, which may serve as second messengers for cell death signaling. Moreover, a recent report showed that ROS participate in TNF- $\alpha$-mediated ceramide generation. ${ }^{18}$ Taken together, these findings suggest the hypothesis that p53-induced ROS production may constitute a signal for ceramide-mediated apoptosis following TNF- $\alpha$ treatment. Restoration of functional p53 by MTp53ts sensitized p53-deficient glioma cells to TNF- $\alpha$ via a pathway involving ROS production, in agreement with a previous report. ${ }^{45}$ Of the antioxidants tested, the ability of Tiron and SOD to partially protect cells expressing functional p53 suggests that $\mathrm{O}_{2}^{-}$plays selective and crucial roles in TNF$\alpha$-induced apoptosis. One interpretation of the partial protec-

tive effect of catalase is that hydrolysis of $\mathrm{H}_{2} \mathrm{O}_{2}$ by catalase accelerates conversion of $\mathrm{O}_{2}^{-\bullet}$ to $\mathrm{H}_{2} \mathrm{O}_{2}$, resulting in the reduction of $\mathrm{O}_{2}^{-\bullet}$ level. However, it should be noted that some p53-deficient human glioma cells died even in the presence of Tiron and SOD, indicating the existence of a ROS-independent death pathway in addition to the ROS-dependent one. The latter pathway is mediated by functional p53. In wild-type p53 glioma cells, depletion of GSH correlated well with the production of $\mathrm{O}_{2}^{-}$measured using the fluorophore $\mathrm{HE}$. GSH depletion was greatly reduced by the $\mathrm{O}_{2}^{-\bullet}$ scavenger, Tiron. Therefore, $\mathrm{O}_{2}^{-\bullet}$ production is responsible for $\mathrm{GSH}$ depletion. GSH depletion functions as an important factor in the activation of N-SMase, but does not affect the activation of A-SMase, as described previously. ${ }^{18,22,46,47}$ It thus appears that p53-mediated ROS-dependent signaling contributes to ceramide generation by $\mathrm{N}-\mathrm{SMase}$, and that the ROSindependent pathway leads to ceramide formation via ASMase. Previous studies ${ }^{18,22,46,47}$ and the present study suggest that depletion of intracellular levels of GSH is closely related to the activation of $\mathrm{N}-\mathrm{SM}$ ase and ceramide formation. However, a recent study demonstrated an indirect physiological effect of GSH depletion on N-SMase activation in TNF- $\alpha$ treated human breast cancer MCF-7 cells. ${ }^{48}$ This finding raises the question what the mechanisms coupling oxidation/ GSH depletion to the activation of N-SMase and undetermined molecule(s) whose own oxidation may regulate $\mathrm{N}$ SMase are.

A recent study suggests the involvement of ceramide in TNF- $\alpha$-induced ROS production. ${ }^{3}$ In contrast, another recent study indicated that ROS participate in TNF-mediated ceramide generation. ${ }^{14}$ In addition, direct inhibition of complex III of the mitochondrial respiratory chain by ceramide ${ }^{49}$ and ceramide-induced cell death via disruption of mitochondrial functions ${ }^{50,51}$ have been demonstrated. In the present study, TNF- $\alpha$-induced ceramide accumulation by $\mathrm{N}$-SMase and mitochondrial changes (decrease in $\Delta \psi \mathrm{m}$ and cytochrome $c$ release) were prevented by the antioxidants Tiron and SOD. Furthermore, GSH and $\mathrm{N}$-acetylcysteine (NAC), which are antioxidants, inhibit the activation of $\mathrm{N}$-SMase by certain apoptotic inducers. ${ }^{22,46,47}$ These findings thus indicate that ceramide produced via A-SMase and N-SMase promoted mitochondrial dysfunction, and that p53-mediated ROS production is located upstream of mitochondrial changes in TNF- $\alpha$-stimulated human glioma cells.

The relationship between caspases and ROS is controversial. ROS are involved in the inactivation of caspases. ${ }^{52}$ On the other hand, caspases function as negative regulators of ROS production. ${ }^{53}$ Most likely, caspases regulate ROS generation since inhibition of caspases results in the blockade of ROS production. ${ }^{54,55}$ In agreement with the latter observation, the present findings indicate that caspase- 8 activation is upstream of ROS production in glioma cells with functional p53 during TNF- $\alpha$-induced apoptosis. The proteolytic processing of caspase-8 was also detected in p53-deficient glioma cells. In addition, accumulation of p53 induced by TNF- $\alpha$ was abrogated by a selective inhibitor for caspase-8, suggesting that caspase-8 activation is located at upstream of p53. Therefore, caspase- 8 may be the common initiator of p53/ ROS-dependent and -independent apoptotic pathways in TNF- $\alpha$-stimulated human glioma cells. 


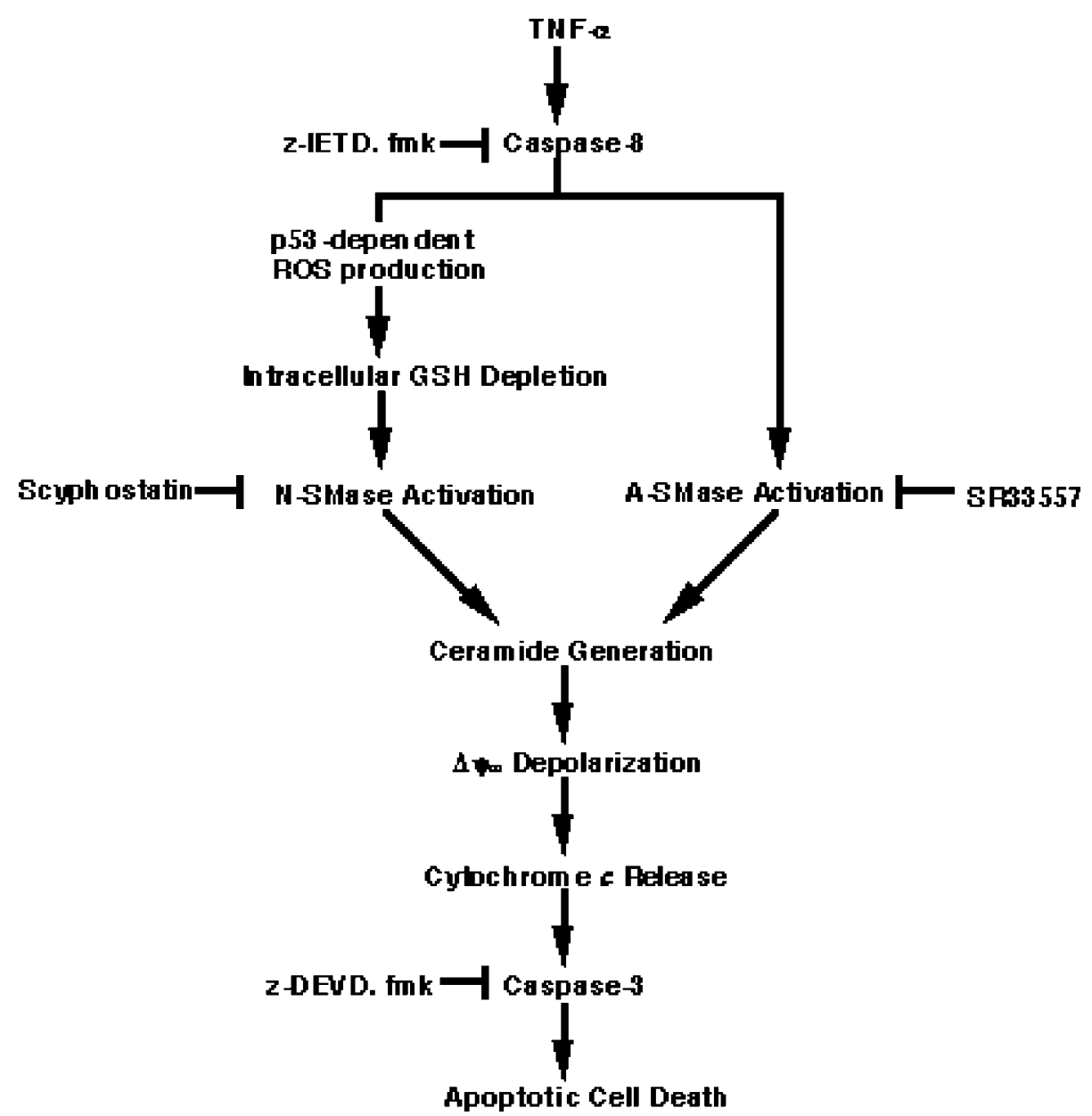

Figure 11 A hypothetical scheme for TNF- $\alpha$-induced signaling cascades in human glioma cells. Two separate signaling cascades, p53-induced ROS-dependent and independent pathways, may contribute to the TNF- $\alpha$-induced ceramide formation. Both pathways are initiated by caspase-8 but not mediated by caspase-3. ROSdependent and -independent pathways lead to ceramide generation via N-SMase and A-SMase, respectively. Ceramide generated through the two separate routes induces $\Delta \psi_{\mathrm{m}}$ depolarization and cytochrome $c$ release, leading to caspase-3 activation and the resultant apoptotic cell death in human glioma cells

In summary, we propose a hypothetical signaling sequence (Figure 11) in which mitochondria participate in TNF- $\alpha-$ induced apoptosis of human glioma cells by $\Delta \psi_{\mathrm{m}}$ alteration and cytochrome $c$ release through ceramide generated via p53-mediated ROS-dependent and -independent pathways, both of which are initiated by the activation of caspase-8. Considering the decreased sensitivity of p53-deficient cells to DNA-damaging agents, TNF- $\alpha$ may potentially be useful for the treatment of gliomas possessing mutant p53 by activating the p53-independent cell death pathway. In addition, further understanding of the SM pathway during TNF- $\alpha$-induced apoptosis in human glioma cells, especially identification of direct targets of ceramide and of the biological mechanism by which ceramide induces mitochondrial dysfunction, may provide a novel approach to treatment of incurable malignant gliomas.

\section{Materials and Methods}

\section{Materials}

Human recombinant TNF- $\alpha$ was purchased from R\&D Systems (Minneapolis, MN, USA). CHX, $\mathrm{DiOC}_{6}(3), \mathrm{CA074} \mathrm{Me}$, and Bafilomycin
A1 were from Sigma (St. Louis, MO, USA). Anticaspase-8 mouse monoclonal antibody (Ab-3), and selective caspase-8 inhibitor, z-IETDfmk, were from Calbiochem-Novabiochem (Cambridge, MA, USA). SR33557 was kindly presented by Dr. J-P Jaffrezou (Claudius Regaud Center, France). Scyphostatin was a generous gift from Dr. T Ogita (Sankyo Co. Ltd., Tokyo, Japan). Other reagents were obtained from previously noted sources. ${ }^{22,56,57}$

\section{Cells and transfections}

The human U-87 MG, U-373 MG, and U-251 MG glioblastoma cell lines were obtained from American Type Culture Collection (Rockville, MD, USA). The cells were maintained in Dulbecco's modified Eagle's medium (DMEM) supplemented with $10 \%$ (v/v) fetal bovine serum (FBS), $100 \mathrm{U} / \mathrm{ml}$ penicillin and $100 \mu \mathrm{g} / \mathrm{ml}$ streptomycin in a humidified atmosphere containing $5 \% \mathrm{CO}_{2}$ at $37^{\circ} \mathrm{C}$. U87-LXSN, U87-W E6, and U87-M E6 cell lines were obtained by infecting U-87 MG cells with LXSN, LXSN-16E6SD, and LXSN-16E6SD-8S9A10T retroviruses, respectively. ${ }^{20-22}$ U-373 MG and U-251 MG cells stably expressing temperature-sensitive p53 mutant, p53ts val ${ }^{138}$ were established, as described previously. ${ }^{22}$ To generate retrovirus vector expressing shRNA, the $3^{\prime}$ LTR in a murine stem cell virus vector, pCMSCVpuro-DEST, was inactivated by an internal deletion (Nhel-Xbal). ${ }^{58}$ The self-inactivating virus vector was named 
pSI-CMSCVpuro-DEST. The H1 promoter cassette with or without stuffer previously described by Brummelkamp et al. ${ }^{59}$ was attached by attB2 and attB1 sequences by adaptor PCR (Gateway system, Invitrogen, Japan), and recombined into pDONR221 by BP reaction (Invitrogen) according to the manufacturer's instruction to generate pENTR221-H1R-stuffer or pENTR-H1R. To generate pENTR221-H1Rp53Ri, the pENTR221-H1Rstuffer was digested with Bgll and Hindll and the annealed oligos (5'gatccccGACTCCAGTGGTAATCTACttcaagagaGTAGATTACCACTGGAGTCtttttggaaa3' and 5'agctttccaaaaaGACTCCAGTGGTAATCTACtctcttgaaGTAGATTACCACTGGAGTCggg $\left.3^{\prime}\right)^{59}$ were replaced with the stuffer. Both the inserts were recombined into pSI-CMSCVpuro-DEST by LR reaction (Invitrogen) according to the manufacture's instruction to generate pSI-CMSCVpuro-H1R-p53Ri and pSI-CMSCVpuro-H1R. U-87 MG cells expressing p53 shRNA and control cells were obtained by infection of SI-MSCVpuro-H1R-p53Ri and the backbone (SI-MSCVpuro$\mathrm{H} 1 \mathrm{R}$ ) retroviruses, respectively, followed by selection with $1 \mathrm{mg} / \mathrm{ml}$ of puromycin. Comparison was performed between U-87 MG cells transduced with SI-MSCVpuro-H1R-p53Ri (designed as U87-p53shRNA) and SI-MSCVpuro-H1R (U87-vector). Prior to treatment with TNF- $\alpha$, the cells were plated at a density of $5 \times 10^{4} / \mathrm{ml}$ and cultured for 2 days.

\section{Nuclear staining}

Apoptotic cells stained with Hoechst 33258 were quantified by fluorescent microscopic analysis. ${ }^{60}$ Briefly, cells were fixed in $1 \%$ glutaraldehyde for $30 \mathrm{~min}$. The cells were then stained with $10 \mu \mathrm{M}$ Hoechst 33258 for $10 \mathrm{~min}$. Nuclear morphology was observed under a fluorescent microscope (Olympus BX60, Tokyo, Japan).

\section{Measurement of cellular ceramide level}

Lipids extracted from cells were first treated in $0.1 \mathrm{M} \mathrm{KOH}$ in chloroform : methanol $(1: 2, \mathrm{v} / \mathrm{v})$ at $37^{\circ} \mathrm{C}$ for $1 \mathrm{~h}^{22,56,57}$ Ceramide was converted to ceramide $1-\left[{ }^{32} \mathrm{P}\right]$ phosphate by Escherichia coli diacylglyceol kinase in the presence of $\left[\gamma-{ }^{32} \mathrm{P}\right] \mathrm{ATP},{ }^{22,56,57}$ and then lipids were separated on high-performance thin-layer chromatography (HPTLC) plates in a solvent system of chloroform:acetone:methanol:acetic acid: water $(50: 20: 15: 10: 5, \mathrm{v} / \mathrm{v})$. Following autoradiography, spots corresponding to ceramide 1-phosphate were scraped into vials and the radioactivity was counted in a scintillation counter (Beckman LS-6500). Quantitation of ceramide was based on a standard curve of known amounts of ceramide. The changes in ceramide content were normalized based on total protein. In some experiments, U-87 MG cells $\left(5 \times 10^{5}\right.$ cells/ $120 \mathrm{ml}$ ) were labeled for $72 \mathrm{~h}$ in the medium containing $25 \mu \mathrm{Ci}$ of $\left[{ }^{14} \mathrm{C}\right]$ serine. The extracted lipids were treated with $0.1 \mathrm{M} \mathrm{KOH}$ and then separated on HPTLC plates using the solvent system of chloroform:methanol : water $(70: 30: 50, v / v)$ for SM or chloroform : methanol $(95: 5$, $\mathrm{v} / \mathrm{v})$ for ceramide. The changes in $\left[{ }^{14} \mathrm{C}\right]$ ceramide and $\left[{ }^{14} \mathrm{C}\right] \mathrm{SM}$ contents were normalized based on total protein.

\section{SMase assay}

The activities of both $\mathrm{N}$ - and $\mathrm{A}$-SMases were determined using a mixed micelle assay system. ${ }^{22,56,57}$ For measuring $\mathrm{N}$-SMase activity, the membrane fractions (20 $\mu \mathrm{g}$ protein) were mixed with [methyl $\left.-{ }^{14} \mathrm{C}\right] \mathrm{SM}$ $(40000 \mathrm{cpm}$ in $1 \mathrm{nmol}$ of bovine brain SM in $0.25 \%$ Triton X-100 solubilized by sonication) in $0.1 \mathrm{M} \mathrm{Tris} / \mathrm{HCl}$ buffer ( $\mathrm{pH}$ 7.4) containing $6 \mathrm{mM}$ $\mathrm{MgCl}_{2}$ and the reaction mixture was incubated for $30 \mathrm{~min}$ at $37^{\circ} \mathrm{C}$. ASMase activity in the membrane was measured as above, except that the Tris/ $\mathrm{HCl}$ buffer was replaced with $0.1 \mathrm{M}$ sodium acetate buffer $(\mathrm{pH} 5.5)$ containing $5 \mathrm{mM}$ EDTA.

\section{Measurement of intracellular GSH level}

Intracellular GSH content was determined according to the previously described method. ${ }^{47,56,57}$ In brief, the harvested cells were suspended in $150 \mu$ of water and 5 -sulfosalicylic acid was added to a final concentration of $2 \%$. The precipitated proteins were pelleted by centrifugation at $2000 \times g$ for $10 \mathrm{~min}$ at $4^{\circ} \mathrm{C}$. Aliquots of the soluble supernatant were mixed with $125 \mathrm{mM}$ sodium phosphate buffer $(\mathrm{pH} 7.5)$ containing $6.3 \mathrm{mM}$ EDTA, $0.21 \mathrm{mM} \mathrm{NADPH}$, and 0.6 mM 5, 5-dithiobis (2-nitrobenzoic acid) in a total volume of $1 \mathrm{ml}$. On addition of glutathione reductase, the increase in absorption at $412 \mathrm{~nm}$ was monitored to determine the amount of GSH in the sample. A reference curve was generated with known amounts of GSH standards.

\section{Detection of ROS and $\Delta \psi_{\mathrm{m}}$}

Intracellular production of ROS was measured by using HE or DCFH-DA. $\mathrm{O}_{2}^{-} \bullet$ is able to oxidize $\mathrm{HE}$ to yield ethidium and $\mathrm{H}_{2} \mathrm{O}_{2}$ is able to oxidize DCFH to DCF. HE dissolved in DMSO or DCFH-DA dissolved in ethanol was incubated with the cells for $5 \mathrm{~min}$ at $37^{\circ} \mathrm{C}$. The final concentrations of $\mathrm{HE}$ and DCFH-DA were 2 and $5 \mu \mathrm{M}$, respectively. For the detection of $\Delta \psi_{\mathrm{m}}$, cells were incubated with $40 \mathrm{nM} \mathrm{DiOC}_{6}(3)$ for $15 \mathrm{~min}$ at $37^{\circ} \mathrm{C}$. After the cells were stained, they were collected in a microcentrifuge. Intracellular ethidium, $\mathrm{DCF}$, or $\mathrm{DiOC}_{6}(3)$ fluorescence was measured by spectrofluorometer (Hitachi F-3000, Japan). In some cases, ethidium, $\mathrm{DCF}$, or $\mathrm{DiOC}_{6}(3)$ fluorescence was visualized with a fluorescent microscope (Olympus BX60, Tokyo, Japan).

\section{Preparation of cytosolic fraction for measurement of cytochrome $c$ release from mitochondria and of cathepsin $B$ release from lysosmes}

Cytosolic extracts were prepared according to the previous report. ${ }^{22}$ Briefly, cells were collected at the indicated times and washed twice with ice-cold PBS and resuspended in $100 \mathrm{ml}$ of extraction buffer $(50 \mathrm{mM}$ HEPES-KOH, pH 7.4, $220 \mathrm{mM}$ mannitol, $68 \mathrm{mM}$ sucrose, $50 \mathrm{mM} \mathrm{KCl}$, $5 \mathrm{mM} \mathrm{EGTA}, 2 \mathrm{mM} \mathrm{MgCl}_{2}, 1 \mathrm{mM}$ dithiothreitol, $1 \mathrm{mM}$ phenylmethylsulfonyl fluoride, and $1 \mathrm{mM} \mathrm{E}-64)$. After incubation on ice for $20 \mathrm{~min}$, cells were homogenized with 20 strokes in a glass homogenizer with a Teflon pestle. Nuclei were removed by centrifugation at $1000 \times g$ for $10 \mathrm{~min}$ at $4^{\circ} \mathrm{C}$ in a microcentrifuge. The resulting supernatants were clarified by centrifugation at $10000 \times g$ for $15 \mathrm{~min}$ and further at $100000 \times g$ for $60 \mathrm{~min}$ at $4^{\circ} \mathrm{C}$.

\section{Western blot analysis}

Cells were solubilized with ice-cold lysis buffer containing $1 \%$ Triton X-100, $50 \mathrm{mM} \mathrm{NaCl}, 25 \mathrm{mM}$ HEPES (pH 7.4), $1 \mathrm{mM}$ EDTA, $1 \mathrm{mM}$ EGTA, $1 \mathrm{mM}$ phenylmethylsulfonyl fluoride, and $10 \mu \mathrm{g} / \mathrm{ml} \mathrm{E}-64$. Extracted proteins $(60 \mu \mathrm{g} /$ well) were separated by sodium dodecylsulfate polyacrylamide gel electrophoresis (SDS-PAGE) on 10 or $15 \%$ polyacrylamide gels, and were electrophoretically transferred onto Immobilon-P membrane. Blocking was performed in Tris-buffered saline containing 5\% skimmed milk powder and $0.1 \%$ Tween-20. The membranes were incubated with the primary antibody and then the secondary antibody coupled with horseradish peroxidase. Detection was performed with ECL system. Protein content was determined with BCA protein assay using bovine serum albumin as a standard.

\section{Statistical analysis}

Data are expressed as means \pm S.D. Significance was assessed by twoway ANOVA, followed by Scheffe's post hoc test. $P$-values less than 0.01 was considered as significant. 


\section{Acknowledgements}

We are grateful to Dr. T Takahashi (Aichi Cancer Center, Japan) for wildtype human p53 plasmid, to Dr. Y Takeuchi (Chester Beatty Laboratories, ICR, UK) for FLYA13 cells, to Dr. J-P Jaffrezou (Claudius Regaud Center, France) for SR33557, and to Dr. T Ogita (Sankyo Co. Ltd, Tokyo, Japan) for scyphostatin. This work was supported in part by the Research Fellowships of the Japan Society for the Promotion of Science for M Sawada (JSPS Research Fellowships for M Sawada). This work was also supported by Grants-in-Aid for Scientific Research (B) (14370429) and Cancer Research (14026065) from The Ministry of Education, Culture, Sports, Science and Technology of Japan.

\section{References}

1. Hennet $T$, Richter $C$ and Peterhans $E$ (1993) Tumor necrosis factor- $\alpha$ induces superoxide anion generation in mitochondria of L929 cells. Biochem. J. 289: 587-592

2. Phelps DT, Ferro TJ, Higgins PJ, Shankar R, Parker DM and Johnson A (1995) TNF- $\alpha$ induces peroxynitrite-mediated depletion of lung endothelial glutathione via protein kinase C. Am. J. Physiol. 269: L551-L559

3. Garcia-Ruiz C, Colell A, Mari M, Morales A and Fesrandez-Checa JC (1997) Direct effects of ceramide on the mitochondrial electron transport chain leads to generation of reactive oxygen species. J. Biol. Chem. 272: 11369-11377

4. Heller RA and Kronke M (1994) Tumor necrosis factor receptor-mediated signaling pathways. J. Cell Biol. 126: 5-9

5. Suzuki YJ, Forman HJ and Sevanian A (1997) Oxidants as stimulators of signal transduction. Free Radic. Biol. Med. 22: 269-285

6. Gotlieb WH, Watson JM, Rezai A, Johnson M, Martinez-Maza O and Berek JS (1994) Cytokine-induced modulation of tumor suppressor gene expression in ovarian cancer cells: up-regulation of p53 gene expression and induction of apoptosis by tumor necrosis factor- $\alpha$. Am. J. Obstet. Gynecol. 170: $1121-1130$

7. Yin D, Kondo S, Barnett GH, Morimura T and Takeuchi J (1995) Tumor necrosis factor- $\alpha$ induces p53-dependent apoptosis in rat glioma cells. Neurosurgery 37: 758-763

8. Cai Z, Capoulade C, Moyret-Lalle C, Amor-Gueret M, Feunteun J, Larsen AK, Bressec-de Paillerets B and Chouaib S (1997) Resistance of MCF7 human breast carcinoma cells to TNF-induced cell death is associated with loss of p53 function. Oncogene 15: 2817-2826

9. Donato NJ and Perez M (1998) Tumor necrosis factor-induced apoptosis stimulates p53 accumulation and p21 $1^{\text {WAF1 }}$ proteolysis in ME-180 cells. J. Biol. Chem. 273: 5067-5072

10. Rokhlin OW, Gudkov AV, Kwek S, Glover RA, Gewies AS and Cohen MB (2000) p53 is involved in tumor necrosis factor- $\alpha$-induced apoptosis in the human prostatic carcinoma cell line LNCaP. Oncogene 19: 1959-1968

11. Johnson TM, Yu ZX, Ferrans VJ, Lowenstein RA and Finkel T (1996) Reactive oxygen species are downstream of p53-dependent apoptosis. Proc. Natl. Acad. Sci. USA 93: 11848-11852

12. Polyak K, Xia Y, Zweier JL, Kinzler KW and Vogelstein B (1997) A model for p53-induced apoptosis. Nature 389: 300-305

13. Li PF, Dietz R and von Harsdorf R (1999) p53 regulates mitochondrial membrane potential through reactive oxygen species and induces cytochrome c-independent apoptosis blocked by Bcl-2. EMBO J. 18: 6027-6036

14. Krown KA, Page MT, Nguyen C, Zechner D, Gutierrez V, Comstock KL, Glembotski CC, Quintana PJ and Sabbadini RA (1996) Tumor necrosis factor $\alpha$-induced apoptosis in cardiac cell death. J. Clin. Invest. 98: 2854-2865

15. Perry DK and Hannun YA (1998) The role of ceramide in cell signaling. Biochem. Biophys. Acta 1436: 233-243

16. Kolesnick RN, Goni FM and Alonso A (2000) Compartmentalization of ceramide signaling: physical foundations and biological effects. J. Cell. Physiol. 184: $285-300$
17. Wiegmann K, Schutze S, Machleidt T, Witte D and Kronke M (1994) Functional dichotomy of neutral and acidic sphingomyelinases in tumor necrosis factor signaling. Cell 78: 1005-1015

18. Singh I, Pahan K, Khan M and Singh AK (1998) Cytokine-mediated induction of ceramide production is redox-sensitive. J. Biol. Chem. 273: 20354-20362

19. Scheffner M, Huibregtse JM, Vierstra RD and Howley PM (1993) The HPV-16 E6 and E6-AP complex functions as a ubiquitin-protein ligase in the ubiquitination of p53. Cell 75: 495-505

20. Kiyono T, Hiraiwa A, Fujita M, Hayashi Y, Akiyama T and Ishibashi M (1997) Binding of high-risk human papillomavirus E6 oncoproteins to the human homologue of the Drosophila discs large tumor suppressor protein. Proc. Natl. Acad. Sci. USA 94: 11612-11616

21. Kiyono T, Foster SA, Koop JI, McDougall JK, Galloway DA and Klingelhutz AJ (1998) Both $\mathrm{Rb} / \mathrm{p} 16^{\text {INK4a }}$ inactivation and telomerase activity are required to immortalize human epithelial cells. Nature 396: 84-88

22. Sawada M, Nakashima S, Kiyono T, Nakagawa M, Yamada J, Yamakawa H, Banno Y, Shinoda J, Nishimura Y, Nozawa Y and Sakai N (2001) p53 regulates ceramide formation by neutral sphingomyelinase through reactive oxygen species in human glioma cells. Oncogene 20: 1368-1378

23. Klingelhutz AJ, Foster SA and McDougall JK (1996) Telomerase activation by the E6 gene product of human papillomavirus type 16. Nature 380 : 79-82

24. Gomez-Manzano C, Fueyo J, Kyritsis AP, Steck PA, Roth JA, McDonnell TJ, Steck KD, Levin VA and Yung WK (1996) Adenovirus-mediated transfer of the p53 gene produces rapid and generalized death of human glioma cells via apoptosis. Cancer Res. 56: 694-699

25. Brann $A B$, Scott $R$, Neuberger $Y$, Abulafia $D$, Boldin $S$, Fainzilber $M$ and Futerman AH (1999) Ceramide signaling downstream of the p75 neurotrophin receptor mediates the effects of nerve growth factor on outgrowth of cultured hippocampal neurons. J. Neurosci. 19: 8199-8206

26. Chen J-K, Capdevila J and Harris RC (2001) Cytochrome P450 epoxygenase metabolism of arachidonic acid inhibits apoptosis. Mol. Cell. Biol. 21: 6322-6331

27. Jaffrezou JP, Levada $T$, Chatelain $P$ and Laurent $G$ (1992) Modulation of subcellular distribution of doxorubicin in multidrug resistant P388/ADR mouse leukemia cells by the chemosensitizer ((2-isopropyl-1-(4-[3- $N$-methyl- $N$ (3,4-dimethoxy-beta-phenethyl)amino]propyloxy)-benzenesulfonyl))indolizine. Cancer Res. 52: 6440-6446

28. Higuchi M, Singh S, Jaffrezou JP and Aggarwal BB (1996) Acidic sphingomyelinase-generated ceramide is needed but not sufficient for TNF-induced apoptosis and nuclear factor- $\kappa$ B activation. J. Immunol. 156: 297-304

29. Harel R and Futerman AH (1993) Inhibition of sphingolipid synthesis affects axonal outgrowth in cultured hippocampal neurons. J. Biol. Chem. 268: 14476-14481

30. Posse de Chaves El, Bussiere M, Vance DE, Campenot RB and Vance JE (1997) Elevation of ceramide within distal neurites inhibits neurite growth in cultured rat sympathetic neurons. J. Biol. Chem. 272: 3028-3035

31. Xie YW, Kaminski PM and Wolin MS (1998) Inhibition of rat cardiac muscle contraction and mitochondrial respiration by endogenous peroxynitrite formation during posthypoxic reoxygenation. Circ. Res. 82: 891-897

32. Moreno-Manzano V, Ishikawa Y, Lucio-Cazana J and Kitamura M (2000) Selective involvement of superoxide anion, but not downstream compounds hydrogen peroxide and peroxynitrite, in tumor necrosis factor- $\alpha$-induced apoptosis of rat mesangial cells. J. Biol. Chem. 275: 12684-12691

33. Michalovitz D, Halevy $O$ and Oren M (1990) Conditional inhibition of transformation and of cell proliferation by a temperature-sensitive mutant of p53. Cell 62: 671-680

34. Vayssiere JL, Petit PX, Risler Y and Mignotte B (1994) Commitment to apoptosis is associated with changes in mitochondrial biogenesis and activity in cell lines conditionally immortalized with simian virus 40 . Proc. Natl. Acad. Sci. USA 91: 11752-11756

35. Petit PX, Lecoeur H, Zorn E, Dauguet C, Mignotte B and Gougeon ML (1995) Alterations in mitochondrial structure and function are early events of dexamethasone-induced thymocyte apoptosis. J. Cell Biol. 130: 157-167

36. Zamzami N, Marchetti P, Castedo M, Zanin C, Vayssiere JL, Petit PX and Kroemer G (1995) Reduction in mitochondrial potential constitutes an early irreversible step of programmed lymphocyte death in vivo. J. Exp. Med. 181: $1661-1672$ 
37. Beidler DR, Tewari M, Friesen PD, Poirier G and Dixit VM (1995) The baculovirus p35 protein inhibits Fas- and tumor necrosis factor-induced apoptosis. J. Biol. Chem. 270: 16526-16528

38. Miura M, Friedlander RM and Yuan J (1995) Tumor necrosis factor-induced apoptosis is mediated by a CrmA-sensitive cell death pathway. Proc. Natl. Acad. Sci. USA 92: 8318-8322

39. Guicciardi ME, Deussing J, Miyoshi H, Bronk SF, Svingen PA, Peter C, Kaufmann SH and Gores GJ (2000) Cathepsin B contributes to TNF- $\alpha$ mediated hepatocyte apoptosis by promoting mitochondrial release of cytochrome c. J. Clin. Invest. 106: 1127-1137

40. Foghshaard L, Wissing D, Mauch D, Lademann U, Bastholm L, Boes M, Elling F, Leist M and Jaattela M (2001) Cathepsin B acts as a dominant execution protease in tumor cell apoptosis induced by tumor necrosis factor. J. Cell Biol. 153: $999-1010$

41. Buttle DJ, Murata M, Knight CG and Barrett AJ (1992) CA074 methylester: a proinhibitor for intracellular cathepsin B. Arch. Biochem. Biophys. 299: 377-380

42. Ishidoh K, Takeda-Ezaki M, Watanabe S, Sato N, Akhara M, Imagwa K, Kikuchi $M$ and Kominami $E$ (1999) Analysis of where and which types of proteinases participate in lysosomal proteinase processing using Bafilomycin A1 and Helicobacter pylori Vac A toxin. J. Biochem. 125: 770-779

43. Nakayama M, Ishidoh K, Kayagaki N, Kojima Y, Yamaguchi N, Nakao H, Kominami E, Okumura K and Yagita $\mathrm{H}$ (2002) Multiple pathways of TWEAKinduced cell death. J. Immunol. 168: 734-743

44. Dbaido GS, Pushkareva MY, Rachid RA, Alter N, Smyth MJ, Obeid LM and Hannun YA (1998) p53-dependent ceramide response to genotoxic stress. J. Clin. Invest. 102: 329-339

45. Shatrov VA, Ameyar M, Bouquet C, Cai Z, Stancou R, Haddada $\mathrm{H}$ and Chouaib S (2000) Adenovirus-mediated wild-type-p53-gene expression sensitizes the resistant tumor cells to the - induced cytotoxity by altering the cellular redox state. Int. J. Cancer 85: 93-97

46. Liu B, Andrieu-Abadie N, Levade T, Zhang P, Obeid L and Hannun YA (1998) Glutathione regulation of neutral sphingomyelinase in tumor necrosis factor- $\alpha$ induced cell death. J. Biol. Chem. 273: 11313-11320

47. Yoshimura S, Banno Y, Nakashima S, Hayashi K, Yamakawa H, Sawada M, Sakai N and Nozawa $Y$ (1999) Inhibition of neutral sphingomyelinase activation and ceramide formation by glutathione in hypoxic PC 12 cell death. J. Neurochem. 73: 675-683

48. Okamoto Y, Obeid LM and Hannun YA (2002) Bcl-xL interrupts oxidative activation of neutral sphingomyelinase. FEBS Lett. 530: 104-108
49. Gudz TI, Tserng KY and Hoppel CL (1997) Direct inhibition of mitochondria respiratory chain complex III by cell-permeable ceramide. J. Biol. Chem. 272 24154-24158

50. Arora AS, Jones BJ, Patel TC, Bronk SF and Gores GJ (1997) Ceramide induces hepatocyte cell death through disruption of mitochondrial function in the rat. Hepatology 25: 958-963

51. Ghafourifar P, Klein SD, Olivier S, Schenk U, Pruschy M, Rocha S and Richter $C$ (1999) Ceramide induces cytochrome $c$ release from isolated mitochondria J. Biol. Chem. 274: 6080-6084

52. Hampton MB and Orrenius S (1997) Dual regulation of caspase activity by hydrogen peroxide: implications for apoptosis. FEBS Lett. 414: 552-556

53. Vercammen D, Beyaert R, Denecker G, Goossens V, Van Loo G, Declercq W, Grooten J, Fiers W and Vandenabeele P (1998) Inhibition of caspases increases the sensitivity of L929 cells to necrosis mediated by tumor necrosis factor. J. Exp. Med. 187: 1477-1485

54. Kruman I, Guo Q and Mattson MP (1998) Calcium and reactive oxygen species mediate staurosporine-induced mitochondrial dysfunction and apoptosis in PC12 cells. J. Neurosci. Res. 51: 293-308

55. Tan S, Sagara Y, Liu Y, Maher P and Schubert D (1998) The regulation of reactive oxygen species production during programmed cell death. J. Cell Biol. 141: 1423-1432

56. Sawada M, Nakashima S, Banno Y, Yamakawa H, Hayashi K, Takenaka K, Nishimura Y, Sakai N and Nozawa $Y$ (2000) Ordering of ceramide formation, caspase activation, and $\mathrm{Bax} / \mathrm{Bcl}-2$ expression during etoposide-induced apoptosis in C6 glioma cells. Cell Death Differ. 7: 761-772

57. Sawada M, Nakashima S, Banno Y, Yamakawa H, Takenaka K, Shinoda J, Nishimura Y, Sakai N and Nozawa $Y$ (2000) Influence of Bax or Bcl-2 overexpression on the ceramide-dependent apoptotic pathway in glioma cells. Oncogene 19: 3508-3520

58. Takeda Y, Mori T, Imabayashi H, Kiyono T, Gojo S, Miyoshi S, Ita M, Segawa K, Ogawa S, Sakamoto M, Nakamura S and Umezawa A. Can the life-span of human marrow stromal cells be prolonged by bmi-1 E6, E7, and/or telomerase without affecting cardiomyogenic differentiation? J. Gene. Med., (in press)

59. Brummelkamp TR, Bernards R and Agami R (2002) A system for stable expression of short interfering RNAs in mammalian cells. Science 296: 550-553

60. Yoshimura S, Banno Y, Nakashima S, Takenaka K, Sakai H, Nishimura Y, Sakai N, Shimizu S, Eguchi Y, Tsujimoto Y and Nozawa Y (1998) Ceramide formation leads to caspase-3 activation during hypoxic PC12 cell death. J. Biol. Chem. 273: 6921-6927 